\title{
Teacher Quality in Public and Private Schools under a Voucher System: The Case of Chile
}

\author{
Jere R. Behrman, University of Pennsylvania \\ Michela M. Tincani, University College London \\ Petra E. Todd, University of Pennsylvania
}

Kenneth I. Wolpin, Rice University

Chile is unusual in having long-term experience with nationwide school vouchers. A key criticism of school voucher systems is that they make it easier for private schools to attract better teachers to the detriment of public schools. This paper uses longitudinal data from Chile to estimate a discrete choice dynamic programming (DCDP) model of teacher and nonteacher labor supply decisions and to explore how wage policies affect the composition of the teacher labor force in public and private schools. In the model, individuals first decide whether to get a teaching degree and then choose annually from among five work/home sector alternatives. Empirical results show that private voucher schools attract better teachers than public schools. However, the existence of the private voucher sector also draws higher-productivity individuals into the teaching profession.

Jere R. Behrman is W. R. Kenan Jr. Professor of Economics and Sociology and a PSC research associate at the University of Pennsylvania. Michela M. Tincani is a lecturer at University College London and a research affiliate at IFS and CeMMAP. Petra E. Todd is Alfred L. Cass Term Professor of Economics, a PSC research associate at the University of Pennsylvania, and an associate of the NBER and

[Journal of Labor Economics, 2016, vol. 34, no. 2, pt. 1]

(C) 2016 by The University of Chicago. All rights reserved. 0734-306X/2016/3402-0006\$10.00

Submitted August 28, 2013; Accepted August 29, 2014; Electronically published January 20, 2016 


\section{Introduction}

In 1981, Chile adopted an innovative nationwide school voucher system for primary and secondary education that still operates today. ${ }^{1}$ The voucher reform dramatically changed the educational landscape, greatly increasing the demand for and the supply of private schools. Attendance at private schools more than doubled, with private schools today accounting for more than half of school enrollment. Although there has been much speculation and debate about likely effects of school voucher programs (e.g., Hoxby 2002, 2003a, 2003b; Neal 2002; Ferreyra 2007), most of the evidence from US data comes from studies examining short-term effects of relatively smallscale privately funded voucher programs (e.g., Rouse 1998; Krueger and $\mathrm{Zhu}$ 2004; Yau 2004). Chile is unique in having long-term experience with a large-scale school voucher system.

School vouchers in Chile are publicly funded, with voucher funds following the child to private schools that agree to accept the voucher as payment of tuition. Both governmental and private schooling sectors coexist with free entry into the private sector and some governmental monitoring of all schools. ${ }^{2}$ There are three broad types of schools: municipal, privatesubsidized, and private-nonsubsidized fee-paying. Until 1993, private subsidized schools and municipal schools were financed primarily through per capita governmental vouchers, but in 1993 there was a change in the rules to allow public and private schools to impose a small tuition charge on top of the voucher. ${ }^{3}$ Private nonsubsidized schools, which include both religious (mainly Catholic) and lay schools, are financed from private tuition. ${ }^{4}$ Parents are free to choose among municipal and both types of private schools. ${ }^{5}$

IZA. Kenneth I. Wolpin is Distinguished Research Professor and Lay Family Professor, Rice University, and professor emeritus, at the University of Pennsylvania and a PSC research associate. We are very thankful for support from the Spencer Foundation. Contact the corresponding author, Petra Todd, at petra@athena.sas .upenn.edu. Information concerning access to the data used in this article is available as supplementary material online.

${ }^{1}$ The voucher reform was one of several privatization and decentralization efforts introduced by Augusto Pinochet's military government.

${ }^{2}$ For example, all schools are required to have licensed teachers. Schools also do not receive additional voucher payments for class sizes that exceed 45 students. See Verhoogen and Urquiola (2009).

${ }^{3}$ Municipal schools sometimes also receive some additional funding in the form of governmental transfers when the voucher amounts are not sufficient to cover the school's operating expenses.

${ }^{4}$ Private subsidized schools can be for-profit or not-for-profit; private nonsubsidized schools are usually for-profit. About three-quarters of private voucher schools are for-profit schools (Elacqua 2006).

${ }^{5}$ In all types of schools, students are required to take standardized tests, called the SIMCE tests. Each year, one or two grades are chosen for these tests among the fourth, eighth, and tenth grades. The school's average test results are published annually, and parents can compare the student's test score performance at locally available schools. 
Advocates of school voucher systems cite their value in fostering competition in both public and private schools and improving school quality (Rouse 1998; Hoxby 2003a, 2003b). Critics caution that they deplete public schools of revenue and of their best teachers (Ladd 2002). Most studies of Chile's school voucher program (e.g., Bravo, Contreras, and Sanhueza 1999; McEwan 2001; McEwan and Carnoy 2001; Contreras 2002; Sapelli and Vial 2002; Tokman 2002; Vegas 2002; Hsieh and Urquiola 2003; Tincani 2014) compare test scores of children in different kinds of public and private schools. The evidence on whether public or private schools are relatively more effective in producing higher math and reading scores is mixed. ${ }^{6}$

It is widely perceived that Chile's 1980 voucher reform led to significant changes in the allocation of teachers across different types of schools, in part because it was accompanied by decentralization measures that transferred the control of public schools to municipal authorities. ${ }^{7}$ Many public school teachers were laid off and had to reapply for their jobs, now in the municipal sector, or find jobs in the private sector. In addition, teacher union contracts were revoked, giving public schools greater flexibility in hiring and firing teachers, and national curriculum standards were relaxed, giving schools more leeway in setting their own curriculum. ${ }^{8}$ After the restoration of the democractic government in 1990, the teacher's association was reinstated and teacher pay was increased, nearly doubling. Today teachers in Chile's public school system again belong to a powerful national teachers' union. Private school teachers are usually members of a smaller, school-level teachers' association, although sometimes they can also be members of the public teachers' association.

One of the key concerns about school voucher systems is that they put private schools in a better position to attract the best teachers to the detriment of public schools. Many education researchers suggest that public school salary schedules create inefficiencies in the teacher labor market because salaries are often based on rigid formulae that depend on experience and educational background and do not respond flexibly to teacher shortages or to reward better teachers. For example, Hoxby (2002) shows that salary schedules in charter and private schools in the United States exhibit less wage compression than in public schools and are more strongly correlated with teachers' backgrounds in math and science, two

${ }^{6}$ Estimation is made difficult by multiple selection problems, namely, that types of children attending each school are self-selected and because unobserved factors that determine student performance are likely to be related to the choice of school.

${ }^{7}$ Prior to these reforms, Chile had a long tradition of providing some public support for private (mainly Catholic) schools, but the introduction of the voucher system greatly increased the level of support going to private schools.

${ }^{8}$ See Carnoy (1997). 
fields in which there are commonly shortages, and with teachers' SAT scores. If private schools are better able to tailor compensation to teaching ability, then, unless there are other compensating factors, one would expect better teachers to select into the private teaching sector where they receive higher wages.

This paper uses data from Chile to study teacher and nonteacher labor supply decisions in a dynamic context. We examine how teacher compensation schedules in the municipal and private teaching sectors affect the decision to become a teacher, the choice of sector in which to work, and the decision about whether to accept a nonteaching job or be out of the labor force. We also investigate the empirical support for whether private voucher schools attract higher-quality teachers than municipal schools on average. In particular, we explore differences in the kinds of teachers who choose to teach in the public and private sectors and the extent to which differences in teacher compensation across public and private sectors explain the selection patterns.

The dynamic decision making model we develop extends earlier models of Stinebrickner (2001a, 2001b) to allow for three teaching sectors (public, private voucher, and private nonvoucher), a nonteaching sector, and a home sector and to incorporate the initial choice about whether to become a certified teacher, which is important to capture labor supply responses of new college graduates. ${ }^{9}$ In the model, individuals first decide whether to obtain teaching certification, and then individuals who are certified receive wage offers and decide among five work/home sector alternatives: (i) work in a municipal school, (ii) work in a private subsidized (voucher) school, (iii) work in a private nonsubsidized school, (iv) work in a nonteaching job, or (v) not work. Individuals who are not certified can only choose iv or v. Labor market experience in teaching and nonteaching accumulates endogenously.

Because fertility is also potentially an important factor related to women's working decisions, the model incorporates fertility as a stochastic process that depends on state variables. The utility from choosing a particular sector in each time period depends both on pecuniary factors (wages) and nonpecuniary factors (e.g., the number of children, perceived benefits). Our model also allows for unobserved heterogeneity in wages and preferences, using the Keane and Wolpin (1997) multinomial types approach. ${ }^{10}$

Our analysis samples are drawn from two longitudinal surveys in Chile. One is a survey called the Encuesta de Protección Social (EPS), which gath-

${ }^{9}$ In Chile, teacher certification is required to work in any type of school.

10 The approach is similar to Heckman and Singer's (1984) use of discrete types in duration analysis. 
ered information from a random sample of working-age Chileans. ${ }^{11} \mathrm{We}$ use data collected in the 2002, 2004, 2006, and 2009 waves. Most relevant for our analysis is the information on demographics, work and lay-off history, fertility, wages, and educational attainment. We use in the estimations individuals who graduated from college or obtained their teaching certification after 1990. Of the 816 such individuals in the EPS sample, $12.1 \%$ received a teaching certificate. Given the small sample size of "teachers" in the EPS survey, we only use the longitudinal information for the 690 "nonteachers" in estimating the model.

For longitudinal information on teachers, we use the ELD (Encuesta Longitudinal Docente), which was collected for the first time in 2005 and then again in 2009 for the purpose of studying the wages and working conditions of teachers and school administrators. The survey was administered to about 6,000 current and former primary and secondary school teachers (as well as a sample of administrators). The data allow study of the labor market outcomes and career trajectories of teachers and how they are affected by the school voucher system and other changes affecting their wages or working conditions. They contain rich retrospective information on education and training and labor force history (total teaching and other experience), as well as 5 years of detailed information on the type of schools in which the teachers/administrators worked. The data also include demographic information (age, gender, fertility, marital status, and family background), starting wage, current wage, hours worked, type of labor market contract, and information on occupational conditions. Our analysis is restricted to individuals in the ELD data who obtained their teaching certification after $1990 .{ }^{12}$ There are 1,401 such individuals, for whom there are 8,147 observations.

The discrete choice dynamic programming (DCDP) model is solved using standard methods (see Keane, Todd, and Wolpin 2010), and the parameters are estimated by simulated method of moments. This estimation procedure permits combining moments from our different data sources (the EPS and the ELD data sets). ${ }^{13}$ After estimating the model, we use it to examine how teacher labor supply, both overall and in the public and private teaching sectors, responds to compensation policies. Results show

${ }^{11}$ The first round of data were collected under the survey name Historia Laboral y Seguridad Social (HLSS). These data were collected by the Microdata Center at the University of Chile, under the leadership of David Bravo.

${ }^{12}$ As noted, the teacher's union was reinstated in 1991, which led to a restructuring of teacher wages. For this reason, we only use in estimation teachers who have been working under the new system. See further discussion below.

${ }^{13}$ Our estimation approach incorporates weights needed to adjust for oversampling of teachers in unsubsidized schools in the ELD and for stratified sampling in the EPS. 
that the teaching sector is composed on the whole of relatively higherproductivity individuals, as captured by the unobserved types in the model, that receive higher wage offers in comparison to the nonteaching sector. Within teaching, the private schooling sectors (both subsidized and unsubsidized) attract higher productivity individuals than does the municipal sector. Simulations based on the estimated model show that increasing the municipal sector wage by $20 \%$ would increase the number of certified teachers but would not increase the "quality" of teachers employed, as the higher wage also attracts lower-productivity types into the teaching profession. ${ }^{14}$

An important distinction between municipal wage offers and private schooling sector wage offers is that the municipal sector has a rigid schedule in which everyone is paid according to their teaching experience and not according to other productivity attributes (e.g., teaching ability). Our simulations show that setting the municipal wage schedule equal to the wage offer function used in the private voucher sector, which distinguishes among productivity types, would generate increases in teacher quality within the municipal sector at the expense of lower teacher quality in the private voucher sector. We also simulate the effect of eliminating the private voucher sector as an employment option, which would increase the quality of teachers who then choose to teach in the municipal schools but would lower the overall average quality of teachers in all sectors. Our empirical results show support for the concern that private voucher schools attract better teachers than municipal schools, largely because they pay higherproductivity teachers more. However, the existence of the private voucher sector also draws higher-productivity individuals into teaching and improves the overall pool of teachers.

The paper proceeds as follows. Section II describes the related literature on teacher labor markets. Section III describes the model, and Section IV describes the estimation approach. Section V discusses the data sources and sample restrictions. Section VI presents the parameter estimates and results based on model simulations.

\section{Related Literature}

There is an extensive literature that analyzes the determinants of entry into and exit from the teaching profession in the United States and in Europe. A smaller literature is concerned with teacher quality and whether and to what extent wage policies can affect teacher quality. We summarize the literature below, grouping the studies into whether they focus on

${ }^{14}$ Manski (1987) reports a similar finding for a static occupational choice model estimated on US data. 
teacher entry, teacher retention, or teacher quality. We also briefly summarize a related literature on the effects of school voucher systems on the productivity of private and public schools.

\section{A. Teacher Entry}

An early study by Manski (1987) used the National Longitudinal Survey of the High School Class of 1972 (NLS-72) to estimate probit models for the teacher/nonteacher occupational choice decision. Manski finds that a general pay increase does not improve teacher quality because it attracts both low- and high-quality teachers to the profession. However, he finds that a $10 \%$ increase in teaching salaries, coupled with a minimum SAT score requirement, would maintain the supply of teachers and, at the same time, raise their average academic ability compared to all college graduates. Shin and Moon (2006), using the National Longitudinal Survey of Young Women, estimates that higher relative salaries are effective in inducing female college graduates to enter into teaching. ${ }^{15}$ Bacolod (2007), using the National Center for Education Statistics Baccalaureate and Beyond Longitudinal Study, estimates nested logit models for the decision to enter into the teaching profession and the decision of whether to teach in urban, suburban, or rural schools. She finds that salaries are important in the occupational entry decision and that working conditions are important in determining where new graduates choose to teach.

Using British 1980 Graduate Cohort data, Dolton (1990) finds that relative starting earnings in teaching and earnings growth are positively related to the probability of becoming a teacher and to teacher retention. Dolton and Mavromaras (1994) investigate how British graduates' occupational choices changed between 1970 and 1980 with reference to the choice of becoming a teacher. They find that the salary responsiveness of females is less than that of males and that the responsiveness declines over time for both females and males. ${ }^{16}$ Wolter and Denzler (2004), using surveys of graduates of Swiss universities for 1981-2001, estimate selection models for salaries of teachers and nonteachers and find positive self-selection of teachers into teaching. Using data for the Norwegian teacher labor market, Falch (2010) estimates the elasticity of teacher labor supply to be about 1.4, with a range of 1.0 to 1.9 , depending on the model specification. HernaniLimarino (2005) examines how well teachers are paid relative to compa-

${ }^{15}$ His estimates control for choice of college majors, but they do not investigate what determines the choice of college major.

${ }^{16}$ The paper also presents a counterfactual prediction of the decisions that each cohort would have made had they experienced the market conditions of the other and estimates a decomposition of the changes in the average probabilities of becoming a teacher due to remunerative and other factors. 
rable nonteachers in 17 Latin American countries. He finds that relative salaries for teachers vary widely across Latin America, with teachers in some countries (Argentina, Chile, Colombia, El Salvador, Honduras, Panama, Paraguay, and Peru) paid more on average than other workers with comparable education, teachers in Nicaragua paid less on average, and teachers in Bolivia, Brazil, Costa Rica, the Dominican Republic, Ecuador, Mexico, Uruguay, and Venezuela paid roughly the same.

Mizala and Romaguera (2005) describe changes over time in the teacher salary structure in Chile. In the 1980s, teachers experienced a 32\% decline in real salaries due to governmental budgetary reductions, and the number of students entering education programs dropped $43 \%$. As previously noted, the teachers' union was reinstated in the early 1990s. Between 1990 and 2002, real teachers' salaries increased $156 \%$. There was a 39\% increase in the number of education students, and the average score on the college entry examination for applicants to education programs increased $16 \%$.

\section{B. Teacher Retention}

Many teachers exit teaching after fairly short employment durations. There have been a number of studies examining the decision to exit from teaching in the United States. Many have used state-level data on teachers working in particular localities, including Michigan (Murnane and Olsen 1989); North Carolina (Murnane and Olsen 1990; Clotfelter et al. 2008; Guarino, Brown, and Wyse 2011); Washington (Theobald 1990; Theobald and Gritz 1996); New York (Reese 1991; Brewer 1996; Mont and Rees 1996; Ondrich, Pas, and Yinger 2008); South Carolina (Richards and Sheu 1992); Texas (Hanushek, Kain, and Rivkin 1999); Pennsylvania (Greenbaum 2002); Missouri (Podgursky, Monroe, and Watson 2004); Wisconsin (Imazeki 2005); and Georgia (Scafidi, Sjoquist, and Stinebrickner 2006). The results indicate that salaries paid to teachers are negatively related to their propensities to exit teaching and positively related to durations in first teaching positions. A common finding is that salary effects are larger for men than for women. Finally, the estimates generally indicate that teachers with higher qualifications (as measured by test scores and degree subject) and those who live in areas with higher average nonteaching salaries are more likely to leave teaching. ${ }^{17}$

A limitation of most of administrative state-level data sets is that they do not follow teachers who move out of state. Stinebrickner (1998, 2001a, 2001b) uses individual-level survey data from the NLS-72, in which teachers who move are followed. Stinebrickner (1998) analyzes data for people

${ }^{17}$ For example, Ingersoll (2003), based on the United States Schools and Staffing Survey and Teacher Follow-up Survey data on public school teachers from 1987 to 2000 , reports that $40 \%-50 \%$ of beginning teachers leave by the end of their fifth year, with higher exits in high-poverty and urban schools and with reported reasons for exiting including job dissatisfaction due to low salaries, lack of support, discipline, or pursuit of better jobs/careers. 
certified as teachers in the period 1975-85; the duration of the first teaching spell was 4 years or less for half of these individuals. He estimates a proportional hazards model for the decision to exit teaching that includes observable demographic and school characteristics as well as school- and individual-level unobservable heterogeneity. He finds that the lengths of teachers' first spells in teaching are more responsive to salaries than to improved working conditions, such as smaller student-teacher ratios. He also finds marriage and fertility to be important determinants of exiting the teaching profession.

Stinebrickner (2001a) uses a DCDP framework similar to the one we use to model the relationship between personal characteristics, salaries, and the decision process of certified teachers. In each school year, the model allows teachers to choose among teaching, nonteaching, and leisure options. The estimated model is used to simulate two counterfactual policies: a uniform teacher salary increase of $25 \%$ and an increase on average of $25 \%$, with the amount of the raise increasing with the Scholastic Aptitude Test (SAT) score of the teacher (as a proxy for ability or quality). His simulations show that salary increases are more likely to reduce the amount of time spent in nonteaching employment than they are to reduce time spent out of the labor force altogether. The wage effect on the decision to continue working as a teacher is greater for men than for women. Both policies raise the fraction of years spent in teaching by approximately the same amount $(0.48$ to 0.72 ), but they differ in the extent to which they attract high-quality teachers, as measured by SAT scores. ${ }^{18}$

Wiswall (2007) extends Stinebrickner's (2001a) occupational choice model to allow for a preliminary stage in which potential teachers decide whether to obtain certification. He estimates a dynamic discrete choice model that he uses to analyze the effects of changes in teacher licensing policy. He finds that more stringent licensing rules reduce teacher labor supply and average teacher quality.

Dolton and van der Klaauw $(1995,1999)$ analyze decisions to leave the teaching profession within a competing risks framework. ${ }^{19}$ The data analyzed are a sample of individuals who graduated from UK universities in 1980 over the years from 1980 to 1987 . Their results indicate the importance of teacher salaries and opportunity wages as determinants of teacher turnover.

Finally, the Falch (2011) study described above also examines the effect of salaries on teacher leaving decisions using a natural experiment approach. Teachers in schools with a lot of prior teacher vacancies received a salary

${ }^{18}$ Stinebrickner (2001b) presents a parallel study using a DCDP framework with a more flexible structure for unobserved heterogeneity but with similar results with regard to teacher supply responsiveness to salary increases.

19 The econometric model allows for a flexible semiparametric specification of the duration dependence structure and of the unobserved heterogeneity distribution in the exit-specific hazard functions. 
premium of about $10 \%$ during $1993-94$ to $2002-3$. Using a school fixed effects model, Falch finds that the salary premium reduces the probability of voluntary quits by 6 percentage points, which implies a short-run labor supply elasticity of about 1.25 .

\section{Teacher Quality}

Ballou and Podgursky (1995) use estimates of entry and exit behavior from other studies to simulate the impact of changing teacher salaries on teacher quality. They conclude that a $20 \%$ increase in salaries would have little impact on teacher quality, because higher salaries reduce exits, which lowers the number of teaching vacancies and reduces incentives to invest in teacher training, particularly for higher-ability individuals with good opportunities elsewhere. They argue that to raise teacher quality, salary increases should be targeted toward those with higher abilities. Ballou and Podgursky (1997) use data from the Schools and Staffing Surveys (SASS) of 1987-88 and 1990-91, the Surveys of Recent College Graduates (SRCG), and SAT scores to examine patterns in teacher pay and teacher quality (as indicated by SAT scores) in the 1980 s among more than 8,000 public schools. They find no significant relationship between state-level changes in teacher salaries and changes in SAT scores or the share of high school students intending to major in education between 1979 and 1989 .

Figlio (2002) uses panel data on new teachers from the SASS supplemented with Common Core Data (CCD) and data from the Census of Governments for newly hired teachers in public school districts that changed their salaries between 1987-88 and 1993-94 to investigate whether school districts can improve the quality of the teachers they hire (as indicated by their having graduated from selective colleges and majored in the subject matter they teach) by unilaterally increasing teacher salaries. For nonunion school districts, he finds a significant positive relation between teacher salaries and that district's probability of hiring well-qualified teachers. This relationship, however, is not found in unionized school districts.

Chen (2009) examines the phenomenon of an oversupply of teachers but a shortage of qualified teachers in Indonesia. Using a sample of collegeeducated workers from the 2001-8 Indonesian Labor Force Surveys and a structural model, he estimates the effect of a proposed teacher law, which could give a significant pay increase (i.e., a 100\% teacher salary increase for certified teachers with a minimum 4-year college education or above). He finds that the relative salary of teachers and of alternative occupations significantly influence teacher entry decision. He also finds that the wage rate set by the teacher law would increase the share of teachers approximately from $16 \%$ to $30 \%$ of the college-educated labor force.

Using data from Chile, Tincani (2014) evaluates the costs and impact of teacher labor market policies on student outcomes. She estimates an equilibrium model of entry into teaching, sorting of teachers across schools, 
parental school choice, and private schools' wage and tuition setting. She uses the estimated model to simulate the effects of different pay and recruitment schemes. She finds that, compared to across-the-board wage increases, wage changes tied to teachers' skill levels are more cost effective at increasing mean student achievement and decreasing the achievement gap by income. Unlike Tincani (2014), the current paper does not examine the equilibrium policy response of parents' and private schools' optimal behavior, and it does not quantify impacts in terms of student outcomes. However, the model in this paper is dynamic, capturing the forward-looking nature of career decisions, whereas Tincani (2014) uses a static model. Parameter estimates are unaffected by the fact that parental behavior is not modeled. Preferences over student characteristics are captured in the model by sector-specific nonpecuniary preference parameters. Sector-specific wage parameters, which are used to infer productivity, are also estimated without bias given that the model accounts for self-selection into sectors.

\section{Effects of Voucher Systems on School Productivity}

There is a growing literature analyzing the effects of voucher reforms on productivity in public and private schools. Bohlmark and Lindahl (2008) analyze the effects of voucher reform introduced in Sweden in 1992. Prior to that time, public schools were virtually the only type of school available. The reform increased the availability of private schools, with the degree of privatization varying significantly across municipalities and over time. Bohlmark and Lindahl (2008) use a difference-in-difference strategy comparing outcomes for cohorts who were exposed and not exposed to the reform and living in municipalities with and without private schools, focusing on ninth-grade students. They find significant short-term effects of private school enrollment over the short term on ninth-grade GPA and on the fraction of students choosing the academic high school track but no longer-term effects. Sandström and Bergström (2005) also analyze the effects of competition on public schools, using Swedish data and using a sample selection model to take into account endogeneity of the choice of school type. The study finds that private school competition promotes improvement in public schools on nationwide standardized test and higher average grades.

A few papers examine the effects of new tuition tax credit policies that effectively reduce the relative price of private schools. Figio and Hart (2014) examine the effects of a means-tested tax credit, the Florida Tax Credit, introduced in 2001. They use a difference-in-difference strategy that compares the change in test scores in public schools in areas that had a high or low degree of private school penetration when the tax credit was introduced. The study finds modestly higher test scores for public school students stemming from increased competition. Chan (2009) uses a similar empirical strategy in analyzing the effects of the 2002 Ontario tuition tax 
credit, which increased access to private schools throughout Ontario. Also using a difference-in-difference analysis, the study finds that public schools that faced a greater degree of competition from private schools experienced greater gains in students' test passing rates.

A study by Card, Dooley, and Payne (2008) uses data from Ontario, Canada, to examine whether a higher degree of competition between the public school system and a Catholic school system that receives equal public funding leads to improved productivity, as measured by test score gains between the third and sixth grades. In particular, it looks at how test scores respond to local school openings. The paper estimates a significant but modest-sized impact of competition on the growth rate of student achievement and finds that extending competition to all students would increase average test scores by $6 \%-8 \%$ of a standard deviation. Gibbons, Silva, and Machin (2008) analyze whether a higher degree of school choice or school competition improves educational outcomes, using administrative data on students in primary schools in southeast England. Using an instrumental variables strategy to address concerns about potential nonrandom sorting of pupils or schools, they find no evidence for a relationship between choice or competition and educational outcomes. However, they find that a certain type of school (called Voluntary Aided schools) experiences better outcomes when there is a higher degree of local school competition. West and Woessmann (2010) use student-level data from 29 countries to analyze whether the share of students in private schools leads to higher achievement on the PISA (Program for International Student Assessment) mathematics, science, and reading exams. Their empirical approach uses historical shares of Catholics living in the country at the end of the nineteenth century as an instrument for the share of private schools today. They find that the share of private schools significantly affects student achievement. Also, much of the positive effect is observed for students attending public schools, suggesting that the benefit comes through increased competition.

There are a few studies examining the relationship between test score performance and private school competition using Chilean data. Gallego (2002) examines changes in SIMCE national standardized test scores between 1994 and 1997 and finds that competition has a positive effect on educational achievement in general but also that the private subsidized schools attract and accept only the academically better students. Auguste and Valenzuela (2003) analyze the relationship between test scores (in the year 2000) and school competition, using an instrumental variables approach to address the potential endogeneity of the school competition measure; they find that more competition increases test scores. ${ }^{20}$ However, Hsieh and Urquiola (2006) reach a different conclusion based on a comparison of average test scores in communities that experienced a greater or

${ }^{20}$ Community population and distance to the closest city serve as instruments. 
lesser increase in private school enrollment. Using community-level data, they find that average standardized test scores did not rise faster in communities where private sector enrollment expanded more. Rather, average repetition and grade-for-age worsened in such areas relative to other communities. $^{21}$

Vegas (2002) uses a data set of teachers in Santiago, Chile, that was collected in 1998-99 that provides information on teacher characteristics and on teachers' perceptions of the schools in which they work and on school management. The teacher data are merged with school-level data on student achievement from national assessment data (the SIMCE data). She finds that differences within sectors in student outcomes and student background and in teacher characteristics are greater than differences between sectors and that a great deal of the variation in student outcomes is unexplained. She finds teacher education, decentralization of decision making, and teacher autonomy to be important factors in explaining student outcomes.

\section{Model}

This section describes the model that we develop and estimate to analyze the initial decision to become certified to teach and subsequent decisions about whether to work, whether to teach, and, if teaching, whether to teach in a public, private-subsidized, or private-unsubsidized school. The DCDP framework that we adopt incorporates forward-looking behavior in which individuals face uncertainty about their future preferences, wage offers, fertility, and layoffs. Model parameters are estimated using information on demographic characteristics (gender, age at certification, fertility), teacher certification, work sector choices, wages, and layoffs. The estimation sample is restricted to college graduates who graduated after $1990 .^{22}$

Individuals are assumed to make choices that maximize in each period their expected discounted value of remaining lifetime utility. In the first model period, individuals decide whether to become certified to teach or to graduate without certification. Thereafter, individuals who have been certified to teach receive wage offers from schools in the municipal sector $(\mathrm{M})$, in the private subsidized/voucher sector $(\mathrm{V})$, and in the private unsubsidized sector (U). They also receive nonteaching wage offers (NT). Those who are not certified to teach only receive offers from the nonteaching sector. Both certified and noncertified individuals can also opt to not work and remain at home $(\mathrm{H})$. After receiving the offers from the

${ }^{21}$ A potential limitation of the analysis is that it examines differences in test scores over time, though the SIMCE tests were not comparable over time prior to 1998, when test equating was introduced.

${ }^{22}$ Teaching in Chile requires a college degree. Additional sample restrictions are described in detail below. 
different sectors, individuals who are certified decide whether to stay home, work in one of the three types of schools, or work in the nonteaching sector. ${ }^{23}$ As described below, individuals also face the possibility of being laid off. The career decision model ends at retirement, assumed to be age 65 for men and 60 for women, the ages at which retirees could obtain pensions during the time period considered. ${ }^{24}$

Teaching experience and nonteaching experience accumulate endogenously in the model. Modeling the endogenous evolution of teaching and nonteaching experience separately is necessary because teaching wages depend on teaching experience. ${ }^{25}$ The initial conditions of the model are gender; the age at which individuals are certified to teach, $a_{i}^{G} \in\{22$, $23, \ldots, 40\}$, for those certified, or else the age of college graduation; and the number of children at the time of certification. The model allows for different unobserved "types" of individuals, denoted by $k$. Types are allowed to differ in skill endowments that may affect wage offers, fertility preferences, and the nonpecuniary value attached to each alternative, as described below. ${ }^{26}$

\section{A. Decision to Become Certified to Teach}

In the initial period, at the age of graduation/certification $a_{i}^{G}$, individual $i$ decides whether to become certified to teach (either by earning an undergraduate or postgraduate degree in education). ${ }^{27}$ The flow utilities

${ }^{23}$ The model does not allow individuals to work in the nonteaching sector before obtaining a teaching certification. In the ELD sample, after applying our sample selection, we observe only seven people with some nonteaching experience at the age of teaching certification. These people have on average 2.3 years of nonteaching experience. In estimation, we set their nonteaching experience at certification to zero.

${ }^{24}$ We assume that the value function is zero after retirement. In principle, different retirement schemes in private and public schools may affect the sectoral choices. However, our sample of teachers comprises young cohorts and, because of discounting, the effect of introducing different retirement schemes would likely be small.

${ }^{25}$ We do not model accumulation of teaching experience by sector separately because in Chile the law states that teaching experience is rewarded by municipal school wages independently of the school sector in which that teaching experience was accumulated.

${ }^{26}$ The types introduce a dimensionality reduction that allows us to identify productivity in different sectors without relying only on the individuals who are observed in multiple sectors, as would be necessary if we estimated a personspecific fixed effect. See Keane and Wolpin (1997).

${ }_{27}$ There are four ways one can become certified to teach in Chile: (i) degree in education (6-11 semesters), (ii) degree in another area (10-12 semesters) + postgraduate degree in education (2-4 semesters), (iii) teaching experience + short university degree ( $2-5$ semesters), and (iv) teaching experience + government authorization. According to the teacher census (Idoneidad Docentes), $90 \%$ of all teachers get certified through channel i, 5\% through channel ii, and 5\% through channels iii and iv. In the model, we do not distinguish between channels $\mathrm{i}$ and ii, and we do not allow for channels iii and iv. 
associated with the education (E) and the nonteaching options (NE) are

$$
\begin{aligned}
U_{i a^{\mathrm{G}}}^{\mathrm{E}} & =\sum_{k} \lambda_{o k}^{\mathrm{E}} \mathrm{I}\left(\text { type }_{i}=k\right)+\lambda_{1}^{\mathrm{E}} \mathrm{D}_{i}^{f}+\lambda_{2}^{\mathrm{E}} a_{i}^{\mathrm{G}}+\eta_{i}^{\mathrm{E}}, \\
U_{i a^{\mathrm{G}}}^{\mathrm{NE}} & =0,
\end{aligned}
$$

where $I($ type $=k)$ is an indicator equal to one if the individual is of type $k$ and $D_{i}^{f}$ is a dummy variable that equals one if female. ${ }^{28}$ It is assumed that the preference shock follows a normal distribution, $\eta_{i}^{E} \sim N\left(0, \sigma_{\eta}^{2}\right)$.

\section{B. Sector Decisions}

Individuals who earn an education degree choose in subsequent periods (until retirement) among five mutually exclusive and exhaustive alternatives: whether to teach in a public municipal $(\mathrm{M})$, or a private-subsidized $(\mathrm{V})$, or a private-unsubsidized (U) school; to work in the nonteaching (NT) sector; or to stay home $(\mathrm{H})$. We denote $d_{i a}^{(1)}=1$ if $\mathrm{M}$ is chosen by individual $i$ at age $a$ (and zero otherwise), $d_{i a}^{(2)}=1$ if $\mathrm{V}$ is chosen (and zero otherwise), $d_{i a}^{(3)}=1$ if $\mathrm{U}$ is chosen (and zero otherwise), $d_{i a}^{(4)}=1$ if NT is chosen (and zero otherwise), and $d_{i a}^{(5)}=1$ if $\mathrm{H}$ is chosen (and zero otherwise).

Period-specific utilities associated with working depend on wages as well as on nonpecuniary factors. ${ }^{29}$ The wage offer schedule in the municipal sector depends only on total teaching experience, reflecting the fact that wages are calculated using a rigid formula according to guidelines set by negotiations between the teachers' union and the government. The wage offer schedule is given by

$$
\ln \left(w_{i a}^{\mathrm{M}}\right)=\alpha_{0}^{\mathrm{M}}+\alpha_{1}^{\mathrm{M}} \mathrm{tx}_{i a}+\alpha_{2}^{\mathrm{M}} \operatorname{tx}_{i a}^{2}+\varepsilon_{i a}^{\mathrm{M}},
$$

where $w_{i a}^{\mathrm{M}}$ is the wage offer to individual $i$ of age $a$ and $\mathrm{tx}_{i a}$ is individual $i$ s total teaching experience (across all teaching sectors). Unobserved skill endowments and gender variables do not enter the municipal wage equation to reflect the institutional feature that municipal wages are centrally determined by the Chilean Teacher's Statute and do not vary by productivity nor gender. The unobserved component of the wage offer, $\varepsilon_{i a}^{\mathrm{M}}$, reflects some adjustments to wages that depend on factors such as working conditions and managerial responsibilities. ${ }^{30}$

${ }^{28}$ The utility for the noneducation option is normalized to zero because only the difference in utilities can be identified.

${ }^{29}$ Utility is assumed to be linear in consumption and additively separable in the nonpecuniary aspects of employment and home. There is thus no motive for saving or borrowing, and consumption is set equal to wages without loss of generality.

${ }^{30}$ Bravo et al. (2010) contains a detailed description of the actual municipal wage formulae from the Estatuto Docente. Consistent with our model, gender does not enter the wage and years of teaching experience do not depend on the sector in which that experience was accumulated. On top of the teaching experience bonus, which is the largest bonus, there are around 20 other types of bonuses that depend 
Wage offers in the other education sectors ( $\mathrm{V}$ and $\mathrm{U}$ ) and in the noneducation sector (NT) are assumed to be based on individual skills. An individual's skill level in the teaching sectors depends on total teaching experience (as in the municipal sector), gender, unobserved type, and an idiosyncratic shock, $\varepsilon_{i a}^{j}, j=\mathrm{V}$, U. An individual's skill level in the nonteaching sector depends on nonteaching experience, $\mathrm{ntx}_{i a}$, total teaching experience, whether the individual has an education degree, $D_{i}^{e}$, gender, unobserved type, and an idiosyncratic shock, $\varepsilon_{i a}^{\mathrm{NT}}$. Wage offers in these sectors are given by

$$
\begin{aligned}
\ln \left(w_{i a}^{\mathrm{V}}\right)= & \sum_{k} I\left(\mathrm{type}_{i}=k\right) \alpha_{0 k}^{\mathrm{V}}+\alpha_{1}^{\mathrm{V}} \mathrm{tx}_{i a}+\alpha_{2}^{\mathrm{V}} \mathrm{tx}_{i a}^{2}+\alpha_{3}^{\mathrm{V}} D_{i}^{f}+\varepsilon_{i a}^{\mathrm{V}}, \\
\ln \left(w_{i a}^{\mathrm{U}}\right)= & \sum_{k} I\left(\mathrm{type}_{i}=k\right) \alpha_{0 k}^{\mathrm{U}}+\alpha_{1}^{\mathrm{U}} \mathrm{tx}_{i a}+\alpha_{2}^{\mathrm{V}} \mathrm{tx}_{i a}^{2}+\alpha_{3}^{\mathrm{U}} D_{i}^{f}+\varepsilon_{i a}^{\mathrm{U}} . \\
\ln \left(w_{i a}^{\mathrm{NT}}\right)= & \sum_{k} I\left(\mathrm{type}_{i}=k\right) \alpha_{0 k}^{\mathrm{NT}}+\alpha_{1}^{\mathrm{NT}} \operatorname{tx}_{i a}+\alpha_{2}^{\mathrm{NT}} \operatorname{ntx}_{i a}+\alpha_{3}^{\mathrm{NT}} \operatorname{ntx}_{i a}^{2} \\
& +\alpha_{4}^{\mathrm{NT}} D_{i}^{e}+\alpha_{5}^{\mathrm{NT}} D_{i}^{f}+\varepsilon_{i a}^{\mathrm{NT}},
\end{aligned}
$$

It is assumed that all (log) wage shocks are normally distributed and independent; any correlation in wage offers across sectors comes through the unobserved types. ${ }^{31}$

Period-specific utilities also depend on nonpecuniary aspects of sectorspecific jobs. Individuals are assumed to vary in their valuations according to their type. In addition, individuals incur search costs associated with switching work sectors, $c^{s}$, being laid off, $c^{l}$, and returning to work after a period of absence, $c^{w}$. The per-period utilities at ages $a>a_{G}$ associated with each work option $j=\mathrm{M}, \mathrm{V}, \mathrm{U}, \mathrm{NT}$ for an individual $i$ of unobserved permanent type $k \in 1,2, \ldots K$ are

on variables that are not observed in our data set. They are not included in our wage equation. The shock in our wage equation is an approximation error that captures these bonuses. Examples of these bonuses are those related to managerial responsibilities, to teaching special types of courses, and to teaching in schools with more than 250 students. The $R^{2}$ for the variables used as moments in the estimation, wage $_{j} \times D_{j}, j \in\{\mathrm{M}, \mathrm{V}, \mathrm{U}\}$, where $D_{j}$ is a dummy equal to one if sector $j$ is chosen, and equal to zero otherwise, represents a lower bound for the $R^{2}$ of the fit of the accepted wage. The fit in municipal schools - where unobserved heterogeneity is not allowed to enter the wage equation - is similar (slightly better) than the fit in private unsubsidized and subsidized schools. Specifically, the $R^{2}$ for municipal schools is .83; for voucher schools it is .82, and for private unsubsidized schools it is .81. This suggests that the assumed municipal wage equation is a good approximation to the governmental formulae.

${ }^{31}$ Like in a classical Ben-Porath framework (Ben-Porath 1967), the wages reflect the product of skills and the price of those skills. Under the normalization of skill prices, the constants in the log-wages are identified up to scale (see, e.g., Heckman and Sedlacek 1985). Therefore, it is possible to rank types in terms of sectorspecific productivity, as we do in the section with the empirical results. 


$$
\begin{aligned}
U_{i a}^{\mathrm{M}} & =w_{i a}^{\mathrm{M}}+\sum_{k} \beta_{0 k}^{\mathrm{M}} I\left(\operatorname{type}_{i}=k\right)+c^{s} I_{C_{s}}+c^{w} I\left[d_{i, a-1}^{(5)}=1\right]+c^{l} I\left[D_{i, a}^{l}=1\right], \\
U_{i a}^{\mathrm{V}} & =w_{i a}^{\mathrm{V}}+\sum_{k} \beta_{0 k}^{\mathrm{V}} I\left(\operatorname{type}_{i}=k\right)+c^{s} I_{C_{s}}+c^{w} I\left[d_{i, a-1}^{(5)}=1\right]+c^{l} I\left[D_{i, a}^{l}=1\right], \\
U_{i a}^{\mathrm{U}} & =w_{i a}^{\mathrm{U}}+\sum_{k} \beta_{0 k}^{\mathrm{U}} I\left(\operatorname{type}_{i}=k\right)+c^{s} I_{C_{s}}+c^{w} I\left[d_{i, a-1}^{(5)}=1\right]+c^{l} I\left[D_{i, a}^{l}=1\right], \\
U_{i a}^{\mathrm{NT}} & =w_{i a}^{\mathrm{NT}}+c^{s} I_{C_{s}}+c^{w} I\left[d_{i, a-1}^{(5)}=1\right]+c^{l} I\left[D_{i, a}^{l}=1\right],
\end{aligned}
$$

where $I_{C_{s}}=I\left[d_{i, a-1} d_{i a}, d_{i, a-1}^{(5)} 1, D_{i, a-1}^{l}=0\right]$ is an indicator for whether the choice represents a switch in sectors, $D_{i, a}^{l}$ equals one if the individual was laid off (and zero otherwise), and $\beta_{0 k}^{j}$ represents the nonpecuniary value of alternative $j=\mathrm{M}, \mathrm{V}, \mathrm{U}$ for type $k$. As seen, an individual who is laid off receives job offers in the same period as the layoff occurs. Finally, the utility associated with staying at home (not working) is

$$
U_{i a}^{\mathrm{H}}=\sum_{k} \beta_{0 k}^{\mathrm{H}}+\beta_{1}^{\mathrm{H}} \mathrm{nk}_{i a} I\left(a_{i} \leq 50\right)+\beta_{2}^{\mathrm{H}} \mathrm{nk}_{i a} D_{i}^{f} I\left(a_{i} \leq 50\right)+\eta_{i a}^{\mathrm{H}},
$$

where nk is the number of children. It is assumed that $\eta_{i a}^{\mathrm{H}} \sim N\left(0, \sigma_{\mathrm{H}}\right) \forall i, a$. The utility from staying home depends on the number of children $\left(\mathrm{nk}_{i a}\right)$, with the dependence gender-specific, restricted to individuals aged 50 or less for whom the children would still be of younger ages. The nonpecuniary value associated with working in the nonteaching (NT) sector is normalized to zero; only the differences in nonpecuniary values are identified.

Fertility is assumed to follow an exogenous stochastic process. In every time period, until age 45 for women and age 50 for men, there is a positive probability, denoted by $p_{i a}^{f}$ of having a child. ${ }^{32}$ That is, $\mathrm{nk}_{i, a+1}=\mathrm{nk}_{i a}+1$ with probability $p_{i a}^{f}, \mathrm{nk}_{i, a+1}=\mathrm{nk}_{i a}$ with probability $1-p_{i a}^{f}$. The probability of having a child depends on the individual's type, gender, the number of children she or he has thus far $\left(\mathrm{nk}_{i a-1}\right)$, and whether there was a birth in the previous period $\left(D_{i, a-1}^{b}\right) .{ }^{33}$ It is specified as a logit,

$$
p_{i a}^{f}=\frac{\exp \left(\sum_{k} \gamma_{0 k}^{f} I(\text { type }=k)+\gamma_{1}^{f} a_{i}+\gamma_{2}^{f} a_{i}^{2}+\gamma_{3}^{f} a_{i} D_{i}^{f}+\gamma_{4}^{f} \mathrm{nk}_{i a-1}+\gamma_{5}^{f} D_{i, a-1}^{b}\right)}{1+\exp \left(\sum_{k} \gamma_{0 k}^{f} I(\text { type }=k)+\gamma_{1}^{f} a_{i}+\gamma_{2}^{f} a_{i}^{2}+\gamma_{3}^{f} a_{i} D_{i}^{f}+\gamma_{4}^{f} \mathrm{nk}_{i a}+\gamma_{5}^{f} D_{i, a-1}^{b}\right)} .
$$

As in the case of fertility, layoffs are treated as an exogenous stochastic process. For individuals in the teaching sector with 15 or fewer years of teaching experience, there is a positive probability of being laid off. Indi-

\footnotetext{
${ }^{32}$ In our sample, only $1.06 \%$ of fathers have a child after age 50 , and only $0.64 \%$ of mothers have a child over age 45 .

${ }^{33}$ Births are unlikely to occur in consecutive years.
} 
viduals with more experience are assumed to have tenure and to not face a risk of lay-off or nonrenewal. ${ }^{34}$ The probability of dismissal/nonrenewal for a teacher, $p_{i a}^{\mathrm{IT}}$, is given by

$$
p_{i a}^{\mathrm{IT}}=\frac{\exp \left(\gamma_{0}^{\mathrm{IT}}+\gamma_{1}^{\mathrm{IT}} \mathrm{tx}_{i a}\right)}{1+\exp \left(\gamma_{0}^{l \mathrm{~T}}+\gamma_{1}^{\mathrm{TT}} \mathrm{tx}_{i a}\right)} .
$$

For individuals working in the nonteaching sector, we similarly assume that there is a positive probability of being laid off that only affects individuals with 15 or fewer years of work experience. The probability of incurring a layoff, $p_{i a}^{\mathrm{INT}}$, is given by

$$
p_{i a}^{\mathrm{INT}}=\frac{\exp \left(\gamma_{0}^{\mathrm{INT}}+\gamma_{1}^{\mathrm{lNT}} \mathrm{ntx}_{i a}\right)}{1+\exp \left(\gamma_{0}^{\mathrm{INT}}+\gamma_{1}^{\mathrm{INT}} \mathrm{ntx}_{i a}\right)} .
$$

In estimation, we assume that there are three unobserved types $(K=3)$ and that the type distribution follows a multinomial logit distribution that depends on the state variables, $\Omega_{i a}{ }^{35}$

$$
\operatorname{Pr}\left(k_{i}=\tau \mid \Omega_{i a}\right)=\frac{e^{\Omega_{i a}^{\prime} \tilde{\omega}_{\tau}}}{\sum_{\tau=1}^{3} e^{\Omega_{i a}^{\prime} \tilde{\omega}_{\tau}}}
$$

We normalize $\omega_{1}=0$ and rewrite the probability of a type as

$$
\operatorname{Pr}\left(k_{i}=\tau \mid X_{i a}\right)=\frac{e^{\Omega_{i a}^{\prime} \omega_{\tau}}}{1+\sum_{\tau=2}^{3} e^{\Omega_{i a}^{\prime} \omega_{\tau}}} .
$$

The state space consists of $\Omega_{i a}=\left[\begin{array}{llllllll}1 & D_{i}^{f} & \operatorname{tx}_{i a} & \mathrm{ntx}_{i a} & \mathrm{nk}_{i a} & d_{i, a-1} & D_{i, a}^{l} & D_{i}^{e}\end{array}\right.$ $\left.a_{i}^{G} \quad D_{i, a-1}^{b}\right]^{\prime} .{ }^{36}$ Specifically, in the above expression,

$$
\begin{aligned}
\Omega_{i a}^{\prime} \omega_{\tau}= & \omega_{\tau 0}+\omega_{\tau 1} D_{i}^{f}+\omega_{\tau 2} \mathrm{tx}_{i a}+\omega_{\tau 3} \mathrm{ntx}_{i a}+\omega_{\tau 4} \mathrm{nk}_{i a}+\omega_{\tau 6} d_{i, a-1}^{(4)}+\omega_{\tau 5} D_{i, a}^{l} \\
& +\omega_{\tau 6} D_{i}^{e}+\omega_{\tau 7} a_{i}^{G}+\omega_{\tau 8} D_{i, a-1}^{b}+\omega_{\tau 9} 1(\mathrm{ELD}) .
\end{aligned}
$$

${ }^{34}$ Very few people with more than 15 years of experience report being laid off. In the sample, $1.25 \%$ of all teachers with at least 16 years of teaching experience are fired or do not get their contracts renewed, as opposed to $2.85 \%$ of less experienced teachers.

${ }^{35}$ We do not allow types to change over time: types capture permanent unobserved heterogeneity. The reason that the type probabilities depend on timevarying variables is because of individuals' self-selection. Individuals are making choices over time that endogenously determine which point in the state space they reach in each time period. Therefore, the distribution of unobserved types across the state space varies over time. To capture this, as an approximation, we let the type probability depend on time-varying state variables.

${ }^{36}$ In the initial time period after graduation, teaching experience, nonteaching experience, the indicator for previous period layoff, and the indicator for a birth in the previous period (which is not observed in the data) are set to zero. 
The last term in the summation is an indicator for whether the individual is from the ELD sample, which allows the type distribution to differ between the ELD and EPS samples. The inclusion of the ELD dummy accounts for the effect of choice-based sampling on the distribution of the unobservable types.

\section{Estimation Approach}

The model does not have an analytical solution and is therefore solved numerically by backward recursion. Model parameters are obtained by the method of simulated moments, choosing the parameters to minimize the weighted average distance between the outcomes simulated under the model and the outcomes observed in the data.

\section{A. Numerical Solution of the Dynamic Programming Problem}

We denote the nonstochastic elements of the state space by $\Omega(a)$ and the stochastic elements (the wage and preference shocks) by $\tilde{\varepsilon}(a)$. Given values for the model parameters $\gamma$, the individual's maximization problem can be written in any period in recursive form. Specifically, the Bellman equation is

$$
V(\Omega(a), \tilde{\varepsilon}(a) ; \gamma)=\max _{d_{i a}}\left\{U_{i a}+\delta E \max \left[V(\Omega(a+1), \tilde{\varepsilon}(a+1) ; \gamma) \mid \Omega(a), d_{i a}\right]\right\}
$$

for $a_{i}$ such that $a_{i}<a_{R}$, where $\delta$ is the discount factor and $a_{R}$ is the age of retirement. In the last decision period, the future $E \max$ is set to 0 . The full solution of the dynamic programming problem is the set of $E$ max functions for all ages. The dynamic programming problem is solved using standard backward recursion methods as described, for example, in Keane et al. (2010).

\section{B. Parameter Estimation}

We estimate the model parameters using a conditional simulated methods of moments approach. ${ }^{37}$ The moments correspond to the squared difference between actual outcomes (wages, occupational choices) for different groups of individuals (e.g., men, women of different ages) and one period ahead model-based forecasts of the outcomes, conditional on state variables. Let $a_{0}$ and $a$ denote the minimum age and maximum age observed in the data, $A$ the set of all ages, and $N_{A}$ the cardinality of the set $A$. Let $\Omega_{i a}$ denote the state space of individual $i$ at age $a$, where $i=1, \ldots, N_{I}, \omega_{i a} \in \Omega_{i a}$ an element of the state space, and $Z_{i a} \subset \Omega_{i a}$ a subset of the state space.

Let $y_{i a}$ denote an observed outcome measure, which in our application corresponds to wages or indicators for whether a particular choice was

${ }^{37}$ See, e.g., Gourieroux and Monfort (2002). 
made, and $\hat{y}_{\text {iask }}(\gamma)$ denote the predicted value of $y_{\text {ia }}$ given model parameters $\gamma$, for simulation number $s$ (where $s=1, \ldots S$ ), and for an individual of type $k$, where $k \in\{1, \ldots, K\}$. The predicted outcome value $\hat{y}_{i a}(\gamma)$ is obtained by integrating over the unobserved type distribution and taking the average over simulation draws. That is,

$$
\hat{y}_{i a}(\gamma)=\frac{1}{S} \sum_{s=1}^{S} \sum_{k=1}^{K} \hat{y}_{i a s k}\left(\gamma ; \Omega_{a}, \text { type }_{i}=k\right) \operatorname{Pr}\left(\text { type }_{i}=k \mid \Omega_{a}\right),
$$

where $\operatorname{Pr}\left(\right.$ type $\left._{i}=k \mid \Omega_{a}\right)$ integrates to one and, as noted, is estimated by a multinomial logit model. The type proportions depend on the state variables (including the fixed initial conditions in the model, gender and age of teaching certification). If the outcome is discrete $(1$ or 0$)$, then $\hat{y}_{i a}(\gamma)$ is the predicted probability (divided by 100) of making the choice of 1 (e.g., the probability of choosing to work in a particular sector).

Both the EPS data and the ELD data were collected using nonrandom sampling schemes. The EPS data were collected by a stratified sampling scheme. The ELD data include all individuals who were teachers in 1995 or later, and the sampling design oversampled private school teachers. Because decisions in our model include the decision to become a teacher and the decision with regard to teacher sector, for our purposes, the ELD sample is a choice-based sample. Weights are included in both the ELD and EPS data sets that reweight the sample back to random sampling proportions (for the ELD sample, random conditional on being a teacher between 1995 and 2002). Our estimation procedure combines moments from the different data sets, and we use the weights in the two data sets to reweight the observations back to random sampling proportions. ${ }^{38}$ The EPS sample is used to get the fraction of teachers certified. Let $w_{i}$ denote the sampling weight of observation $i$, which does not vary by age. ${ }^{39}$ For the ELD sample, we only use observations on outcomes of individuals beginning with the first year after they become teachers (with the state variables referring to their first year of teaching).

We now consider a moment corresponding to the mean squared difference between actual and simulated outcomes for individuals with a particular subset of conditioning state variables $Z_{i a}$ and of an age in the range $\tilde{A} \in A$. Let $D_{i, Z_{i a}, \tilde{A}}=1$ if $\omega_{i a} \in Z_{i a}$ and $a \in \tilde{A}$, else $=0$. Let $N=N_{A} \times N_{I}$, where $N_{I}$ is the number of individuals and $N_{A}$ the number of ages over

${ }^{38}$ Recall that we also account for potential sample selection based on unobservables through the inclusion of an ELD indicator variable in the type probability function.

${ }^{39}$ The weights are normalized to sum to the total numbers of observations in the data (respectively, for the two data sets). For the EPS, we use the weights provided in the 2004 survey. For the ELD, we use the weights provided in the 2005 survey. 
which they are observed. ${ }^{40}$ We can write the $i$ th moment condition as follows: ${ }^{41}$

$$
f_{N}^{i}(\gamma)=\left[\frac{1}{N} \sum_{i=1}^{N} \sum_{a=a_{0}}^{a^{\prime}}\left(y_{i a}-\hat{y}_{i a}(\gamma)\right) D_{i, Z_{i a}, \tilde{A}} w_{i}\right]
$$

where $w_{i}$ denotes the sampling weights. In the limit, as $N_{I} \rightarrow \infty$ and $S \rightarrow \infty$, the above expression converges to

$$
E\left(y_{i a}-\hat{y}_{i a}(\gamma) \mid D_{i, Z_{i a}, \tilde{A}}=1\right) \operatorname{Pr}\left(D_{i, Z_{i a}, \tilde{A}}=1\right) .
$$

Stack all the moment conditions into the $m \times 1$ vector $f_{N}(\gamma)$. The estimator minimizes the criterion

$$
\hat{\gamma}=\arg \min f_{N}(\gamma)^{\prime} W_{N}(\gamma) f_{N}(\gamma)
$$

where $W_{\mathrm{N}}$ is the $m \times m$ dimensional weighting matrix. Let $V_{\mathrm{N}}$ denote the sample variance of the moment vector. Also, $W$ and $V$ are the probability limits of $W_{\mathrm{N}}$ and $V_{\mathrm{N}}$. The method of moments estimator is distributed as

$$
\sqrt{N}(\hat{\gamma}-\gamma) \sim\left(N\left(0,\left(\Gamma W \Gamma^{\prime}\right)^{-1}\left(\Gamma^{\prime} W V W \Gamma\right)\left(\left(\Gamma^{\prime} W \Gamma^{\prime}\right)^{-1}\right)\right) .\right.
$$

The optimal weighting matrix (the one that leads to the most efficient GMM estimator) sets $W_{N}=V_{N}^{-1}$. We do not use the optimal weighting matrix in estimation, however, because it is a large matrix that is difficult to invert in a numerically precise way. The formula given above, which allows for a nonoptimal weighting matrix, does not require inversion of $V$. Appendix A provides detailed information on how $\Gamma, V$, and $W$ are estimated.

${ }^{40}$ For ease of notation, we abstract from possibly having an unbalanced panel.

${ }^{41}$ For wage outcomes, we match the product of the wage and the sector dummy. For example, if $y_{i a}^{\mathrm{M}}$ denotes the wage offer in sector $\mathrm{M}$ and $D_{i a}^{\mathrm{M}}$ is equal to one if sector $\mathrm{M}$ is chosen, we build a simulated outcome $\hat{y}_{i a}^{M} \hat{D}_{i a}^{\mathrm{M}}$ for municipal sector wages. The corresponding moment condition is

$$
\frac{1}{N} \sum_{i=1}^{\mathrm{N}} \sum_{a=a_{0}}^{a^{\prime}}\left(y_{i a}^{\mathrm{M}} D_{i a}^{\mathrm{M}}-\hat{y}_{i a}^{\mathrm{M}} \hat{D}_{i a}^{\mathrm{M}}\right) D_{i, Z_{i a}, \tilde{A}} w_{i} .
$$

Because the sector choice is an endogenous outcome, the simulated dummy depends on the parameters and its presence introduces discontinuity in the objective function used in estimation. To guarantee asymptotic normality, we assume the sufficient condition for smoothness of the limiting objective function of the MSM presented in theorem 7.1 in Newey and McFadden (1994). Under this assumption, the results of theorem 7.1 apply and the estimator is asymptotically normal. Given the complexity of the model, this assumption is imposed instead of derived from the model primitives. 


\section{Data Description and Sample Restrictions}

In 2002, the Microdata Center of the Department of Economics of the Universidad de Chile conducted a new household survey called Historia Laboral y Seguridad Social (HLLS). In 2004, 2006, and 2009, it administered follow-up surveys, changing the name of the survey to the Encuesta de Protección Social (EPS; Social Protection Survey). The data from the EPS, as previously noted, contain demographic and labor market information on 17,246 individuals age 15 or older, including information on household characteristics, education, training and work history, pension plan participation, and savings, as well as more limited information on health, assets, disability status, and utilization of medical services. Of particular relevance to our analysis are the questions on labor force and participation in training/education, which include retrospective labor force participation and layoff information (back to 1981), information on educational attainment and fertility, and information on wages for the survey years. In our estimation, we use individuals who graduated from college or graduate school and/or obtained teaching certification in or after 1990. The reason for this restriction is that the government introduced the Estatuto Docente in 1991, which dramatically changed teaching in municipal schools. Before its introduction, municipal school teachers were not considered public employees; they were subject to the private labor code, had less job security, and the wages were not regulated. The Estatuo Docente introduced the wage formulae for public school teachers and also increased the wage level. Because the characteristics of the teaching profession changed so dramatically (at least in municipal schools), we decided to analyze only decisions for the subset of teachers who entered under the new system.

The second longitudinal survey we use is the Encuesta Longitudinal Docentes (ELD; Longitudinal Survey of Teachers), collected for the first time in 2005 and 2009 for the purpose of studying the wages and working conditions of teachers and school administrators. The survey was administered to 6,000 current and former primary and secondary school teachers. ${ }^{42}$ The data contain rich retrospective information on education and training and labor force history (total teaching and other experience), as well as 5 years of detailed information on the type of schools in which the teachers/ administrators worked. The survey also gathered demographic information (age, gender, fertility, marital status, family background), health information, starting wages, current wages, hours worked, type of labor market contract, and information on occupational conditions. Our analysis is restricted to individuals in the ELD data who obtained their teaching certification after

${ }^{42}$ The sampling frame for the ELD consisted of teachers in 1995 (obtained from the teacher census) and of individuals who entered into the teaching profession since 1995. Therefore, the ELD covers individuals who over the last 20 years were at some point teachers. 
1990 with a certification age below or equal to age 40 , of which there are 1,401 individuals. We have 8,147 person-year observations.

\section{Empirical Results}

\section{A. Parameter Estimates}

Table 1 shows the estimated model parameters. ${ }^{43}$ The model was estimated incorporating three unobserved types to capture unobservable heterogeneity. The preference parameters associated with having an education degree relative to a noneducation college degree are negative for all three types, indicating that, other things equal, people have a preference for noneducation degrees. The coefficient on the female indicator is positive, showing that men dislike education degrees more than women.

The coefficients under the panel labeled "Payoff: Municipal Schools" show the parameters of the wage-offer equation (the $\alpha s$ ) and the nonpecuniary returns (the $\beta_{0 j}^{\mathrm{M}^{\prime}} s, j=1,2,3$ ). Similarly, the panels labeled "Payoff: Voucher Schools," "Payoff: Unsubsidized Schools," and "Payoff: Nonteaching Sector" show the same parameters for the other sectors. With respect to the wage offer functions, in accordance with union wage schedules, wage offers in municipal schools depend on teaching experience but do not differ by type or gender. On the other hand, voucher and unsubsidized schools, which must compete with municipal schools for teachers, are less constrained by union wage negotiations and are thus able to discriminate among teachers through the wages they offer. Similarly, wage offers in the nonteaching sector, encompassing a variety of industries and occupations, would be expected to vary by type (and gender).

The estimates in table 1 reveal significant differences in wage offers by type and gender in nonmunicipal schools and in the nonteaching sector. With respect to gender, for given experience and type, women receive a $10 \%$ lower wage offer than men in voucher schools, an $8 \%$ lower wage offer in unsubsidized schools, and a $27 \%$ lower offer in nonteaching jobs. There are also large differences in wage offers among the unobserved types. Type $1 \mathrm{~s}$ receive the lowest wage offers in all sectors and type $2 \mathrm{~s}$ the highest in all sectors. Relative to the municipal schools, for which all types receive the same offers, type $1 \mathrm{~s}$ are the only group that receives lower offers in all of the other sectors. We therefore interpret type $1 \mathrm{~s}$ as the lowest productivity type and type $2 \mathrm{~s}$ as the highest.

Experience returns also differ across sectors. For example, the first year of experience adds $5.4 \%$ to wages in voucher schools but only $2.5 \%$ in municipal schools. After 10 years of experience, the voucher school wage will have increased by about $40 \%$ but only by about $10 \%$ in municipal

${ }^{43}$ Because of the relatively short panel, we did not estimate the discount factor, which was set at 0.96 . 
Table 1

Parameter Estimates for the DCDP Model

\begin{tabular}{lrlc}
\hline Utility of Obtaining an Education Degree & \multicolumn{2}{c}{ Payoff: Nonteaching Sector } \\
\hline Type 1: $\lambda_{01}$ & $-2.610 \mathrm{E}+08$ & Type 1: $\alpha_{01}^{\mathrm{NT}}$ & 14.95 \\
& $(2.20 \mathrm{E}+05)$ & & $(.017)$ \\
Type 2: $\lambda_{02}$ & $-8.011 \mathrm{E}+07$ & Type 2: $\alpha_{02}^{\mathrm{NT}}$ & 15.93 \\
& $(7.41 \mathrm{E}+05)$ & & $(.016)$ \\
Type 3: $\lambda_{03}$ & $-9.821 \mathrm{E}+07$ & Type 3: $\alpha_{03}^{\mathrm{NT}}$ & 15.51 \\
& $(1.19 \mathrm{E}+05)$ & & $(.017)$ \\
Female: $\lambda_{1}$ & $6.390+\mathrm{E} 07$ & Teaching experience: $\alpha_{1}^{\mathrm{NT}}$ & .028 \\
& $(6.78 \mathrm{E}+04)$ & & $(1.46 \mathrm{E}-05)$ \\
Age at graduation/ & & Nonteaching experience: & \\
certificate $: \lambda_{2}$ & $1.280 \mathrm{E}+06$ & $\alpha_{2}^{\mathrm{NT}}$ & .055 \\
& $(198.40)$ & $($ Nonteaching & $(6.63 \mathrm{E}-05)$ \\
SD: $\sigma_{\eta}$ & 18.56 & experience $)^{2}: \alpha_{3}^{\mathrm{NT}}$ & -.00243 \\
& $(.021)$ & & $(3.49 \mathrm{E}-06)$ \\
& & Has an education degree: & -.176 \\
& & $\alpha_{4}^{\mathrm{NT}}$ & $(3.94 \mathrm{E}-04)$ \\
& & Female: $\alpha_{5}^{\mathrm{NT}}$ & -.286 \\
& & & $(3.34 \mathrm{E}-04)$ \\
& &
\end{tabular}

\begin{tabular}{|c|c|c|c|}
\hline \multicolumn{2}{|c|}{ Payoff: Municipal Schools } & \multicolumn{2}{|c|}{ Payoff: Home Sector } \\
\hline Constant term: $\alpha_{0}^{\mathrm{M}}$ & $\begin{array}{l}15.00 \\
(.025)\end{array}$ & Type 1: $\beta_{01}^{\mathrm{H}}$ & $\begin{array}{l}1.301 \mathrm{E}+06 \\
(1,909.97)\end{array}$ \\
\hline Experience: $\alpha_{1}^{\mathrm{M}}$ & $\begin{array}{l}.025 \\
(4.23 \mathrm{E}-05)\end{array}$ & Type 2: $\beta_{02}^{\mathrm{H}}$ & $\begin{array}{l}-1.465 \mathrm{E}+08 \\
(38,343.19)\end{array}$ \\
\hline$(\text { Experience })^{2}: \alpha_{2}^{\mathrm{M}}$ & $\begin{array}{l}-.0015 \\
(1.70 \mathrm{E}-07)\end{array}$ & Type 3: $\beta_{03}^{\mathrm{H}}$ & $\begin{array}{l}3.947 \mathrm{E}+05 \\
(1,694.61)\end{array}$ \\
\hline $\begin{array}{l}\text { Nonpecuniary, } \\
\text { type } 1: \beta_{01}^{\mathrm{M}}\end{array}$ & $\begin{array}{l}-3.975 \mathrm{E}+06 \\
(1,145.86)\end{array}$ & $\begin{array}{l}\text { Number of children } \\
\times \text { age }<51: \beta_{1}^{H}\end{array}$ & $\begin{array}{l}3.120 \mathrm{E}+05 \\
(135.43)\end{array}$ \\
\hline $\begin{array}{l}\text { Nonpecuniary, } \\
\text { type 2: } \beta_{02}^{\mathrm{M}}\end{array}$ & $\begin{array}{l}4.973 \mathrm{E}+06 \\
(187.09)\end{array}$ & $\begin{array}{l}\text { Number of children } \\
\quad \times \text { female } \times<51: \beta_{1}^{\mathrm{H}}\end{array}$ & $\begin{array}{l}1.120 \mathrm{E}+05 \\
(107.37)\end{array}$ \\
\hline $\begin{array}{l}\text { Nonpecuniary, } \\
\text { type } 3: \beta_{03}^{\mathrm{M}}\end{array}$ & $\begin{array}{l}1.235 \mathrm{E}+06 \\
(715.21)\end{array}$ & & \\
\hline
\end{tabular}

\begin{tabular}{lccc}
\hline \multicolumn{2}{c}{ Payoff: Voucher Schools } & \multicolumn{2}{c}{ Transition Costs } \\
\hline Type 1: $\alpha_{01}^{\mathrm{V}}$ & 14.88 & Switching sectors, not at & \\
& $(.005)$ & home last period: $c^{s}$ & $-2.524 \mathrm{E}+08$ \\
Type 2: $\alpha_{02}^{\mathrm{V}}$ & 17.03 & Laid off from teaching & $(432,527.46)$ \\
& $(.004)$ & last period: $c^{l}$ & $-2.394 \mathrm{E}+07$ \\
& & & $(12,423.37)$ \\
Type 3: $\alpha_{03}^{\mathrm{V}}$ & 15.06 & Home last period: $c^{w}$ & $-7.598 \mathrm{E}+06$ \\
Experience: $\alpha_{1}^{\mathrm{V}}$ & $(.020)$ & & $(9,538.76)$ \\
& .054 & & \\
& $(1.07 \mathrm{E}-04)$ & & \\
& & & \\
& & & \\
& & & \\
& & &
\end{tabular}


Table 1 (continued)

\begin{tabular}{|c|c|c|c|}
\hline \multirow[b]{2}{*}{$(\text { Experience })^{2}: \alpha_{2}^{\mathrm{V}}$} & \multirow[b]{2}{*}{$\begin{array}{l}-.00144 \\
(1.84 \mathrm{E}-06)\end{array}$} & \multicolumn{2}{|c|}{ Log of the SD of Payoffs } \\
\hline & & Municipal sector: $\sigma^{\mathrm{M}}$ & $\begin{array}{l}-.347 \\
(5.01 \mathrm{E}-04)\end{array}$ \\
\hline Female: $\alpha_{3}^{\mathrm{V}}$ & $\begin{array}{l}-.105 \\
(5.54 \mathrm{E}-05)\end{array}$ & Voucher sector: $\sigma^{\mathrm{V}}$ & $\begin{array}{l}-.270 \\
(2.87 \mathrm{E}-04)\end{array}$ \\
\hline $\begin{array}{l}\text { Nonpecuniary, } \\
\text { type } 1: \beta_{01}^{\mathrm{V}}\end{array}$ & $\begin{array}{l}-4.891 \mathrm{E}+07 \\
(866.01)\end{array}$ & Unsubsidized sector: $\sigma^{\mathrm{U}}$ & $\begin{array}{l}-.765 \\
(1.43 \mathrm{E}-03)\end{array}$ \\
\hline $\begin{array}{l}\text { Nonpecuniary, } \\
\text { type } 2: \beta_{02}^{\mathrm{V}}\end{array}$ & $\begin{array}{l}-2.688 \mathrm{E}+07 \\
(543.18)\end{array}$ & Nonteaching sector: $\sigma^{\mathrm{NT}}$ & $\begin{array}{l}-.119 \\
(1.70 \mathrm{E}-04)\end{array}$ \\
\hline $\begin{array}{l}\text { Nonpecuniary, } \\
\text { type } 3: \beta_{03}^{\mathrm{V}}\end{array}$ & $\begin{array}{l}8.255 \mathrm{E}+05 \\
(913.04)\end{array}$ & Home sector: $\sigma^{\mathrm{H}}$ & $\begin{array}{l}1.34 \mathrm{E}+01 \\
(.016)\end{array}$ \\
\hline \multicolumn{2}{|c|}{ Payoff: Unsubsidized Schools } & \multicolumn{2}{|c|}{ Fertility Process } \\
\hline Type 1: $\alpha_{01}^{\mathrm{U}}$ & $\begin{array}{l}14.90 \\
(.004)\end{array}$ & Type 1: $\gamma_{01}^{f}$ & $\begin{array}{r}-9.25 \\
(.039)\end{array}$ \\
\hline Type 2: $\alpha_{02}^{\mathrm{U}}$ & $\begin{array}{l}16.70 \\
(.013)\end{array}$ & Type $2: \gamma_{02}^{f}$ & $\begin{array}{r}-9.49 \\
(.031)\end{array}$ \\
\hline Type 3: $\alpha_{03}^{\mathrm{U}}$ & $\begin{array}{l}15.16 \\
(.016)\end{array}$ & Type 3: $\gamma_{03}^{f}$ & $\begin{array}{l}-.468 \\
(7.11 \mathrm{E}-04)\end{array}$ \\
\hline Experience: $\alpha_{1}^{\mathrm{U}}$ & $\begin{array}{c}.075 \\
(9.93 \mathrm{E}-05)\end{array}$ & Age: $\gamma_{1}^{f}$ & $\begin{array}{c}.049 \\
(8.08 \mathrm{E}-05)\end{array}$ \\
\hline$(\text { Experience })^{2}: \alpha_{2}^{\mathrm{U}}$ & $\begin{array}{l}-.0020 \\
(2.24 \mathrm{E}-06)\end{array}$ & $(\mathrm{Age})^{2} \gamma_{2}^{f}$ & $\begin{array}{l}-.003 \\
(4.46 \mathrm{E}-06)\end{array}$ \\
\hline Female: $\alpha_{3}^{\mathrm{U}}$ & $\begin{array}{l}-.078 \\
(6.20 \mathrm{E}-05)\end{array}$ & Age $\times$ female: $\gamma_{3}^{f}$ & $\begin{array}{l}-.012 \\
(7.22 \mathrm{E}-06)\end{array}$ \\
\hline $\begin{array}{l}\text { Nonpecuniary, } \\
\text { type } 1: \beta_{01}^{\mathrm{U}}\end{array}$ & $\begin{array}{l}-3.081 \mathrm{E}+07 \\
(999.64)\end{array}$ & Number of children: $\gamma_{4}^{f}$ & $\begin{array}{c}.233 \\
(2.04 \mathrm{E}-04)\end{array}$ \\
\hline $\begin{array}{l}\text { Nonpecuniary, } \\
\text { type } 2: \beta_{02}^{\mathrm{U}}\end{array}$ & $\begin{array}{l}-3.139 \mathrm{E}+07 \\
3,881.44)\end{array}$ & Birth last period: $\gamma_{5}^{f}$ & $\begin{array}{r}-1.312 \\
(.002)\end{array}$ \\
\hline $\begin{array}{l}\text { Nonpecuniary, } \\
\text { type } 3: \beta_{03}^{\mathrm{U}}\end{array}$ & $\begin{array}{l}-2.804 \mathrm{E}+05 \\
(387.88)\end{array}$ & & \\
\hline Dismissal Pr & & & \\
\hline Constant: $\gamma_{0}^{\mathrm{IT}}$ & $\begin{array}{r}-2.904 \\
(.005)\end{array}$ & & \\
\hline Teaching experience: $\gamma_{1}^{\mathrm{IT}}$ & $\begin{array}{l}-.148 \\
(1.80 \mathrm{E}-04)\end{array}$ & & \\
\hline Constant: $\gamma_{0}^{1 \mathrm{NT}}$ & $\begin{array}{r}-2.197 \\
(.003)\end{array}$ & & \\
\hline $\begin{array}{l}\text { Nonteaching } \\
\quad \text { experience: } \gamma_{1}^{\mathrm{INT}}\end{array}$ & $\begin{array}{l}-.082 \\
(9.11 \mathrm{E}-05)\end{array}$ & & \\
\hline
\end{tabular}


Table 1 (continued)

\begin{tabular}{|c|c|c|c|}
\hline \multicolumn{2}{|c|}{ Probability of Type 2} & \multicolumn{2}{|c|}{ Probability of Type 3} \\
\hline Constant: $\omega_{20}$ & $\begin{array}{r}-2.465 \\
(.010)\end{array}$ & Constant: $\omega_{30}$ & $\begin{array}{l}-.243 \\
(.022)\end{array}$ \\
\hline Female: $\omega_{21}$ & $\begin{array}{r}-1.250 \\
(.006)\end{array}$ & Female: $\omega_{31}$ & $\begin{array}{l}.035 \\
(.018)\end{array}$ \\
\hline Teaching experience: $\omega_{22}$ & $\begin{array}{l}-1.564 \\
(7.60 \mathrm{E}-04)\end{array}$ & Teaching experience: $\omega_{32}$ & $\begin{array}{l}.105 \\
(5.47 \mathrm{E}-05)\end{array}$ \\
\hline$(\text { Teaching experience })^{2}$ : & & $(\text { Teaching experience })^{2}$ : & \\
\hline$\omega_{23}$ & $\begin{array}{l}.135 \\
(.002)\end{array}$ & $\omega_{33}$ & $\begin{array}{l}.083 \\
(.017)\end{array}$ \\
\hline Number of children: $\omega_{24}$ & $\begin{array}{l}.793 \\
(.012)\end{array}$ & Number of children: $\omega_{34}$ & $\begin{array}{l}2.739 \\
(.013)\end{array}$ \\
\hline $\begin{array}{l}\text { Nonteaching sector last } \\
\text { period: } \omega_{25}\end{array}$ & $\begin{array}{l}-.711 \\
(.119)\end{array}$ & $\begin{array}{l}\text { Nonteaching sector last } \\
\text { period: } \omega_{35}\end{array}$ & $\begin{array}{l}-.566 \\
(.003)\end{array}$ \\
\hline $\begin{array}{l}\text { Laid off from teaching } \\
\text { last period: } \omega_{26}\end{array}$ & $\begin{array}{l}5.840 \\
(.037)\end{array}$ & $\begin{array}{l}\text { Laid off from teaching } \\
\text { last period } \omega_{36}\end{array}$ & $\begin{array}{r}-9.350 \\
(.010)\end{array}$ \\
\hline $\begin{array}{l}\text { Age at graduation/ } \\
\text { certification: } \omega_{27}\end{array}$ & $\begin{array}{c}-.0056 \\
(.001)\end{array}$ & $\begin{array}{l}\text { Age at graduation/ } \\
\text { certification: } \omega_{37}\end{array}$ & $\begin{array}{l}-.080 \\
(8.92 \mathrm{E}-04)\end{array}$ \\
\hline Birth last period: $\omega_{28}$ & $\begin{array}{l}1.630 \\
(.004)\end{array}$ & Birth last period: $\omega_{38}$ & $\begin{array}{r}-2.500 \\
(.013)\end{array}$ \\
\hline In ELD sample: $\omega_{\text {ELD }}$ & $\begin{array}{l}.315 \\
(.094)\end{array}$ & In ELD sample: $\omega_{\text {ELD }}$ & $\begin{array}{l}5.803 \\
(.001)\end{array}$ \\
\hline
\end{tabular}

NOTE.-The three types refer to three unobserved heterogeneity types included in estimating the model. Standard errors are in parentheses.

schools. The experience return is largest in the unsubsidized sector, with the first year of experience adding $7.5 \%$ to the wage offer. The first-year return to (sector-specific) experience in the nonteaching sector is similar to that in the voucher sector, but it declines faster with additional years of experience. Interestingly, there is a nontrivial return $(2.8 \%)$ to teaching experience in the nonteaching sector, but those with teaching certification receive $17.6 \%$ lower wage offers in the nonteaching sector.

Type-specific choices are determined not only by wage offers but also by the value placed on sector-specific nonpecuniary aspects of employment. Recall that the coefficients in table 1 representing these nonpecuniary returns are relative to the returns in the nonteaching sector. Among the teaching sectors, all of the types value most the nonpecuniary aspects of employment in municipal schools. However, type $1 \mathrm{~s}$ value the nonpecuniary aspects of employment in the nonteaching sector more than those in the teaching sectors, while both type $2 s$ and $3 s$ value those in the municipal sector more than in the nonteaching sector. Only type $1 \mathrm{~s}$ value being at home more than working in any of the sectors. Type 2 s place a greater value 
on working in the municipal sector and in the nonteaching sector than on remaining at home, but a lower value on working in the other sectors, and type $3 \mathrm{~s}$ place a greater value on working in the voucher sector than on remaining at home, but a lower value on working in other sectors. The estimates for the home sector payoff also reveal that children increase the value of remaining at home, more so for women than for men.

With respect to some of the other parameters, the transition (search) costs associated with switching work sectors, switching from the home sector to working and during a layoff are estimated to be substantial in magnitude. The probability of a birth increases with age at a decreasing rate, with births more likely for individuals with more children and less likely if there was a birth in the previous period. The estimated parameters for the dismissal process show that dismissals are a decreasing function of experience, both in the teaching and nonteaching sectors.

\section{B. Discussion: Types and Teacher Productivity}

As noted in, for example, Hanushek and Rivkin (2006), the literature on the estimation of cognitive achievement production functions has developed mostly separately from the literature on teacher labor supply: the studies that estimate teacher effectiveness from data on student test scores abstract from teacher labor supply decisions, and vice-versa. Within the teacher labor supply literature, different studies have used different measures of teacher quality, for example, teacher experience, qualifications, and measures of teacher cognitive skills. In this paper, we use teacher productivity as valued by the labor market to measure teacher quality, and we examine how productivity varies by unobserved (and observed) teacher characteristics. This is important because studies using test scores to estimate teacher quality find that it varies substantially among teachers and that it is related to unobserved teacher characteristics (see, e.g., Rivkin, Hanushek, and Kain 2005). We study how opportunity wages in nonteaching occupations affect the decision to enter and stay in the teaching profession because previous studies show that wages in the nonteaching sector are an important determinant of the decision to become a teacher (e.g., Dolton and Van der Klaauw 1999). We adopt a rich framework in which we allow productivity in the nonteaching sector to differ from productivity in the teaching sector. Our estimation results show that individuals who are more productive in the nonteaching sector are also more productive in the teaching sector. This is consistent with previous studies that found that increasing nonteaching sector wages reduces the quality of the teaching force (e.g., Corcoran, Evans, and Schwab 2004).

In the context of Chile, Tincani (2014) finds that the measure of teacher productivity we use affects student test scores positively; types who obtain higher wages in private schools increase student test scores by more. 
Bravo, Flores, and Medrano (2010) find that private school teacher wages increase with teacher cognitive skills, as measured by the teacher's PAA score (Prueba de Aptitud Académica, the Chilean equivalent of the SAT score), and that teachers' PAA scores are positively correlated with student test scores. Finally, Correa, Parro, and Reyes (2017) find positive selection of teachers into private schools, using a Roy model (Roy 1951), where, like in this paper, teacher quality is measured by labor market productivity.

\section{Descriptive Statistics and Model Fit}

Tables 2 and 3 present descriptive statistics and evidence on the model fit, based on one-step-ahead simulations. ${ }^{44}$ That is, for each person-year observation, we simulate their wage offers and derive their choices conditional on the observed state variables. In the data, $17.8 \%$ of female college graduates in the EPS sample have education degrees in comparison to $6.1 \%$ of men. Simulations based on the model come very close to replicating these proportions.

Of the women who are certified to teach, $33.8 \%$ are employed in municipal schools, $48.3 \%$ in voucher schools, $11.8 \%$ in unsubsidized private schools, and $2.2 \%$ in nonteaching. For college graduates without teaching certification, $75.7 \%$ of women are employed in comparison to $85.2 \%$ of men. Simulations of the choice distribution based on the model are within 1-3 percentage points of the data. ${ }^{45}$ The model fit to accepted wages is also close; the deviations are generally less than $5 \%$.

There is a strong propensity for those with an education degree to remain employed in the same school sector from one year to the next. In particular, 96.8\% who are employed in a municipal school in one year are employed in a municipal school the next year. The corresponding figure for those in a voucher school is $96.2 \%$, and for those in an unsubsidized school it is $93.4 \%$. Simulated data are quite close, $95.7 \%, 96.1 \%$, and $90.8 \%{ }^{46}$

Table 3 provides information about how the types differ and about how types are distributed in the population. The first row of the table shows the fraction of men and women college graduates estimated to be of each type. As seen, $73.0 \%$ of females are estimated to be of type $1,1.8 \%$ of type 2 , and $25.3 \%$ of type 3 . The type distribution is similar for men, with $72.1 \%$ type $1,6.0 \%$ type 2 , and $22.1 \%$ type 3 . The type distribution is much different for those who chose an education degree. For women, type $3 \mathrm{~s}$ comprise almost three-fourths of all college graduates with an education

${ }^{44}$ The means shown in the table incorporate sampling weights.

${ }^{45}$ The simulations are based on 40 simulation draws.

${ }^{46}$ Although all of these are close quantitatively to the actual data, a chi-square test rejects the hypothesis that they are the same for all but the voucher schools. The chi-square test does not correct the degrees of freedom for estimated parameters in the simulated data. 
Table 2

Model Fit to Sample Statistics Based on One-Step-Ahead Simulations

\begin{tabular}{|c|c|c|}
\hline & Actual & Model \\
\hline \multicolumn{3}{|c|}{ Proportion with education degree: } \\
\hline Female & .178 & .177 \\
\hline Male & .061 & .062 \\
\hline \multicolumn{3}{|c|}{ Proportion of teachers employed in: } \\
\hline \multicolumn{3}{|c|}{ Municipal schools: } \\
\hline Female & .338 & .348 \\
\hline Male & .296 & .318 \\
\hline \multicolumn{3}{|c|}{ Voucher schools: } \\
\hline Female & .483 & .506 \\
\hline Male & .482 & .512 \\
\hline \multicolumn{3}{|c|}{ Unsubsidized schools: } \\
\hline Female & .118 & .124 \\
\hline Male & .140 & .150 \\
\hline \multicolumn{3}{|c|}{ Nonteaching jobs: } \\
\hline Female & .022 & .014 \\
\hline Male & .041 & .013 \\
\hline \multicolumn{3}{|c|}{ Proportion of nonteachers employed: } \\
\hline Female & .757 & .785 \\
\hline Male & .852 & .885 \\
\hline \multicolumn{3}{|c|}{ Mean accepted wages (in 1,000 pesos): } \\
\hline \multicolumn{3}{|c|}{ Teachers in municipal schools: } \\
\hline Female & 4,989 & 4,858 \\
\hline Male & 5,352 & 4,652 \\
\hline \multicolumn{3}{|c|}{ Teachers in voucher schools: } \\
\hline Female & 5,586 & 6,459 \\
\hline Male & 6,320 & 7,715 \\
\hline \multicolumn{3}{|c|}{ Teachers in unsubsidized schools: } \\
\hline Female & 6,412 & 5,287 \\
\hline Male & 7,208 & 6,108 \\
\hline \multicolumn{3}{|c|}{ Nonteachers: } \\
\hline Female & 5,809 & 5,211 \\
\hline Male & 8,264 & 7,681 \\
\hline
\end{tabular}

degree, while for men, type 2 s and type 3 s comprise $94 \%$ of college graduates with an education degree, split almost evenly between the two types. Recalling that table 2 showed that type 1 individuals are the least productive in all sectors in terms of having lower wage offers, our results imply that people who are certified to teach are generally drawn from the higher productivity types among college graduates.

\section{Policy Simulations}

In all simulations we assume that the market for teachers is competitive and that all teachers teach if they want to at equilibrium wages. Table 4 simulates the effect of a variety of policy interventions that have the 
Table 3

Distribution of Types by Gender and Degrees

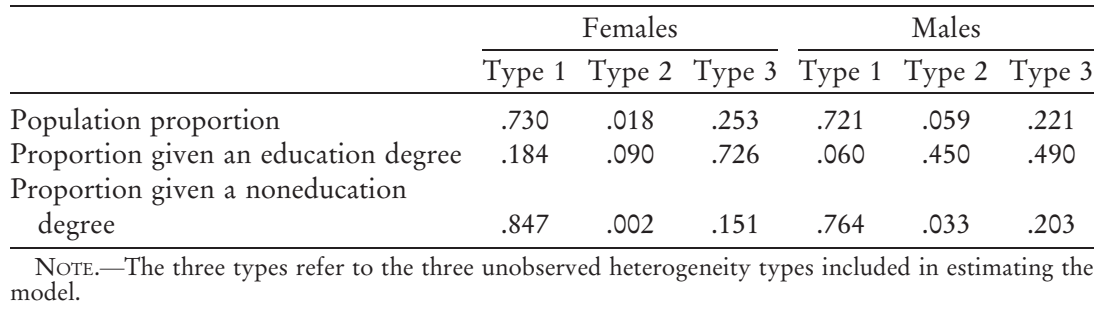

potential to attract higher-productivity types into teaching and into the municipal sector. ${ }^{47}$ These include $(a)$ a bonus to getting an education degree in the amount of 2 years of municipal wages, $(b)$ a $20 \%$ increase in the municipal sector teacher wage offer, and $(c)$ the municipal sector adopting the same wage schedule as the private voucher sector. ${ }^{48} \mathrm{We}$ also consider a more radical type of policy that eliminates the voucher school option for teachers to see if the availability of the voucher schools lowers the quality of teachers in the municipal sector.

For each of the policy simulations, we start with the initial conditions for each person and simulate an entire career path for 100 sets of simulation draws. ${ }^{49}$ That is, we simulate the decisions individuals make about whether to obtain an education degree and whether and where to work. Table 4 reports the averages across the simulations for what the population would look like in 2004-7.50

The columns under "Baseline" show the type distributions based on the model estimates. As seen, in the baseline, $12.1 \%$ of college graduates receive an education degree; $15 \%$ of them are type $1 \mathrm{~s}, 18.0 \%$ are type $2 \mathrm{~s}$, and $66.7 \%$ are type $3 \mathrm{~s}$. Of those receiving education degrees, almost all $(98.6 \%)$ who work in municipal schools or in unsubsidized schools are type 3 , while there is close to an even split of those who work in voucher schools among type $2 \mathrm{~s}(57.2 \%)$ and type $3 \mathrm{~s}(42.7 \%)$. In fact, type $2 \mathrm{~s}$, the most productive teachers, are found only in the voucher schools.

The first policy simulation evaluates the effect of giving a bonus for obtaining an education degree in the amount of 2 years of municipal entrylevel wages. As seen in the first row of table 1, the bonus would increase

\footnotetext{
${ }^{47}$ We are not considering in these simulations equilibrium effects and school budget constraints.

${ }^{48}$ Chile recently introduced a policy that provides fellowships to individuals who graduate with an education degree.

${ }^{49}$ Our simulated policy effects use the EPS distribution of initial conditions (gender, age at graduation, and number of children) rather than the ELD, because the EPS sample is nationally representative and includes both teachers and nonteachers.

50 These years correspond to those in which the EPS data were collected.
} 





the percentage of women obtaining an education degree from $17.7 \%$ to $18.7 \%$ and the proportion of men from $6.2 \%$ to $6.7 \%$. However, it would also lead to an increase in the percentage of low-productivity (type 1) individuals among those earning an education degree, from $18.4 \%$ to $19.3 \%$ for women and from $6.0 \%$ to $6.7 \%$ for men, and a reduction in the percentage of the highest productivity type (type 2 ).

The second policy intervention we consider is a $20 \%$ increase in the municipal wage. The simulation shows that the wage increase leads to an increase in the percentages of individuals obtaining an education degree from $12.1 \%$ to $13.6 \%$ and, as with the first policy, to an increase in the share of type $1 \mathrm{~s}$ among teachers (from $15.3 \%$ to $17.9 \%$ ). Moreover, many of the type 1 new entrants choose municipal sector employment, increasing their share from only $1.4 \%$ to $21.5 \%$ of municipal sector teachers. ${ }^{51}$ Thus, average teacher quality in the municipal sector falls. This policy also induces type $3 \mathrm{~s}$ working in the voucher schools to move to the municipal schools, so that type $2 \mathrm{~s}$ are essentially the only teachers in the voucher schools.

In our next policy simulation, municipal schools adopt a wage offer function identical to that used in the private voucher schools. Similar in magnitude to the case of the $20 \%$ increase in the municipal wage, $13.7 \%$ of college graduates choose an education degree. However, unlike that previous policy, this policy induces the highest productivity types to enter the teaching profession. Specifically, the fraction of those with an education degree who are type $2 \mathrm{~s}$ increases from the baseline case of $18.0 \%$ to $27.3 \%$. Moreover, not only are the new entrant type $2 \mathrm{~s}$ drawn to the municipal sector, but so are those who were working in the voucher schools. Indeed, almost all of the type $2 \mathrm{~s}$ are now working in the municipal sector, accounting for over one-half $(53.0 \%)$ of municipal sector teachers. ${ }^{52}$

The last policy simulation considers the impact of eliminating the voucher school sector as an employment option for teachers. This change would lower the percentage of college graduates receiving an education degree from $12.1 \%$ to $10.4 \%$, with the fall being especially large for men (from $6.2 \%$ to $3.8 \%$ ). With the absence of voucher schools, all of the type 2s (all of whom were in voucher schools in the baseline) move to the

${ }^{51}$ They also choose to work in the small unsubsidized sector.

${ }^{52}$ Because the model is partial equilibrium in nature, the counterfactual results implicitly assume that labor demand in all sectors is infinitely elastic at equilibrium wages. Also, if teachers care about the identity of students, then some of the counterfactual experimental results may be affected. For example, we find that an increase in the municipal wage increases the relative supply of less productive individuals to the municipal sector. If high-ability students are more likely to move to private schools as a result, and if high-ability teachers prefer high-ability students, then some high-ability teachers would move to private schools, and the quality of teachers in municipal schools would be lower than our simulation predicts. 
municipal schools, with type $2 \mathrm{~s}$ now comprising $11.7 \%$ of the municipal school teachers (7.8\% of female teachers and $31.2 \%$ of male teachers). However, the type distribution for those with an education degree would also change, with the share of type 2 s dropping by two-thirds (from $18.0 \%$ to $6.5 \%)$.

\section{Conclusions}

Chile's long-term experience with school vouchers on a nationwide scale provides a unique opportunity to learn how teacher labor markets operate under a voucher system. In Chile, the market for private education is competitive, and more than half of children attend private schools. Proponents of school voucher systems cite their value in fostering competition and improving the overall quality of public and private schools. Critics often emphasize that voucher systems draw the best teachers out of the public school system and into the private system.

In this paper, we developed and estimate a discrete choice dynamic programming (DCDP) model of occupational choices, and we use it to evaluate a range of potential policies for improving the quality of teachers. The model builds on earlier related models of Stinebrickner (2001a, 2001b), extending his framework to allow for three teaching sectors (public, private voucher, private nonvoucher), as well as a nonteaching sector and home sector, and to incorporate the initial choice about whether to become a certified teacher.

The estimated model parameters show that unobservable heterogeneity, incorporated in the model through three discrete types, is an important feature of the data. ${ }^{53}$ We found evidence of absolute advantage, namely, that the types are ranked in the same way in terms of productivity across all sectors, with type 1 having the lowest productivity and type 2 the highest.

Simulations based on the estimated model yield a number of interesting findings. First, among college graduates in Chile, people who enter the teaching profession are drawn from the higher-productivity types (types 2 and 3). Second, private voucher schools attract higher-quality teachers than do municipal schools. Third, if the municipal sector were to adopt the voucher sector wage schedule that tailors pay to type of teacher, the quality of municipal school teachers would increase.

Fourth, it is difficult to increase the quality of teachers in the municipal sector simply by increasing teacher pay there. Increasing municipal teacher wages by $20 \%$ does not increase quality because low-productivity types are also drawn into that sector. It is possible that increasing pay to induce more entry combined with minimum standards could increase teacher quality, but imposing a minimum standard is outside the scope of our model.

${ }^{53}$ See Keane and Wolpin (1997) for another example of an occupational choice model where unobservable heterogeneity plays an important role. 
Fifth, giving a bonus for getting an education degree induces more people to major in education but does not substantially affect the quality.

Sixth, we performed a simulation that examines how the composition of teachers would change if the private voucher school sector were eliminated as an employment option. We find that not having a private voucher sector would increase the quality of teachers in municipal schools. However, this benefit comes at a cost of lowering the overall quality of teachers. The existence of a private voucher sector, where teacher wages are competitively determined, attracts higher productivity individuals into the teaching profession. ${ }^{54}$

Considering the common criticisms of voucher systems, we find support for the concern that private voucher schools are able to attract better teachers than municipal schools, largely because they pay higherproductivity teachers more. But the pool of teachers is not fixed, and the existence of the private voucher sector draws higher-productivity individuals into the teaching sector and improves the overall pool of people choosing teaching as a profession.

\section{Appendix A}

\section{Estimation of the Weighting Matrix and of the Limiting Distribution}

As noted in the text, for a general weighting matrix $W$, the method of moments estimator is distributed as

$$
\sqrt{N}(\hat{\gamma}-\gamma) \sim\left(N\left(0,\left(\Gamma W \Gamma^{\prime}\right)^{-1}\left(\Gamma^{\prime} W V W \Gamma\right)\left(\left(\Gamma^{\prime} W \Gamma^{\prime}\right)^{-1}\right)^{\prime}\right) .\right.
$$

For ease of exposition, in describing the construction of the variancecovariance matrix of the moments, $V$, consider a vector of a set of two moments corresponding to outcomes $y_{i a}^{1}$ and $y_{i a}^{2}$. The second moment uses observations for which $D_{i, Z_{i a}^{\prime}, \tilde{A}^{\prime}}=1$, which may overlap with the set of observations for which $D_{i, Z_{i a}, \tilde{A}}=1$.

$$
f_{N}(\gamma)=\left[\begin{array}{c}
\frac{1}{N} \sum_{i=1}^{N} \sum_{a=a_{0}}^{a^{\prime}}\left(y_{i a}^{1}-\hat{y}_{i a}^{1}(\gamma)\right) D_{i, Z_{i a},{ }^{,}{ }^{2} w_{i}} \\
\frac{1}{N} \sum_{i=1}^{N} \sum_{a=a_{0}}^{a^{\prime}}\left(y_{i a}^{2}-\hat{y}_{i a}^{2}(\gamma)\right) D_{i, Z_{i a}^{\prime}, \tilde{A}^{\prime}{ }^{\prime} w_{i}}
\end{array}\right] .
$$

${ }^{54}$ We do not allow for teacher effort because we do not have the necessary data. Were the data available, allowing for teacher effort would be an interesting extension. Given this nontrivial change to the model, however, we cannot speculate with confidence about how that extension would affect the counterfactual results. 
To simplify the notation, we suppress the dependence of $\hat{y}$ on $\gamma$. A consistent estimator of the asymptotic variance-covariance matrix of the parameter estimates substitutes $\hat{V}_{N}$ and $\hat{\Gamma}_{N}$, where the estimator for $V$ is

$$
\begin{aligned}
& \hat{V}_{N}=\left(\frac{1}{N}\right)^{2} \times \sum_{i=1}^{N_{I}} \sum_{a=a_{0}}^{a^{\prime}} \sum_{=a_{0}}^{a^{\prime}}
\end{aligned}
$$



The off diagonal terms for any two moments that are based on different individuals (or different data sets) will be zero (i.e., zero covariance). For moments based in part on the same individuals, there are variance terms and covariance terms (capturing the correlations across ages).

The matrix $\Gamma$ is the matrix of derivatives of each of the moments with respect to the model parameters. Let $K$ denote the number of parameters (dimension of $\gamma$ ) The dimensionality of $\Gamma$ is $K \times m$. For example, for two moments, the $\Gamma^{\prime}$ matrix is

$$
\Gamma^{\prime}=\left[\begin{array}{c}
\frac{\partial f_{N}^{1}(\gamma)}{\partial \gamma^{\prime}} \\
\frac{\partial f_{N}^{2}(\gamma)}{\partial \gamma^{\prime}}
\end{array}\right]_{2 \times K} .
$$

The derivatives that make up the elements of the $\Gamma$ matrix are estimated by numerical derivatives. Let $\gamma_{i}$ denote the $i$ th element of $\gamma$ and let $\Delta_{i}$ denote the same size vector $\Delta_{i}$ that is zero everywhere except in the $i$ th element, which is a small positive number. Then the derivative of moment $m$ with respect to $\gamma_{i}$ is estimated by

$$
\frac{\partial \widehat{f_{N}^{m}(\gamma)}}{\partial \gamma_{i}}=\frac{f_{N}^{m}\left(\gamma+\Delta_{i}\right)-f_{N}^{m}(\gamma)}{\Delta_{i}} .
$$

The weighting matrix $W$ is a diagonal matrix that does not depend on the parameter values. The diagonal elements are chosen to make the magnitude of the different moments roughly comparable. Specifically, we compute the mean of the outcome to which each moment refers and use one over the mean as the weight. For example, for wages in a given sector, we compute the average wage in that sector (for people who actually work in that sector) and the weight is one over the mean. A similar weight is used for the moments representing proportions.

\section{Appendix B}

\section{Moments Used in Estimation}

To use separate simulation algorithms and separate state spaces, we separate the EPS data set into certified teachers (EPSt) and nonteachers 
(EPSnt). EPSnt has a sample size of 697 and a total number of person-year observations of 6,841 .

\section{B1. Moments Using Data from Age $a_{\mathrm{G}+1}$ to Age $a_{\mathrm{R}}$}

Moments from the age of graduation/certification $\left(a_{\mathrm{G}+1}\right)$ to the age of retirement $\left(a_{\mathrm{R}}\right)$ refer to outcomes and choices subsequent to the decision on whether to get a teaching degree. The options for certified and noncertified teachers are different (noncertified teachers cannot teach); hence the algorithm that simulates one-step ahead forecasts is different for certified teachers and nonteachers. Moreover, simulations are conditional on the state space, which is different for different individuals.

Because of the different problems that certified teachers and nonteachers solve, we match different moments to the different data sets: ELD, EPSt, and EPSnt. In all three data sets, we only use cells that contain at least 20 observations. A cell is defined by the value of the variables on which the moment is conditioned, so, for instance, the size of the cell "outcome1 by gender $=$ female" is the number of women for whom we have both a real outcome and a simulated outcome. A simulated outcome exists if and only if all the variables in the current state space are nonmissing.

We grouped together cells for which there were too few observations in a way that maintained variation, so, for example, if there were three age categories, we would not group together all three age categories because by doing so we would lose the age variation.

\section{Moments Based on the ELD Data Set}

We match 229 moments to the ELD. We do not use the year after they initially become certified to teach (which is why age starts at 23 and not at 22). The following are the categories used in constructing the moments based on the ELD data:

- agecat1 separates age into the following three categories: [23, 34], $[35,44],[45,54]$.

- agecat 1 males separates the age of males into the following categories, and it is used only for the fertility moments: [23, 44], [45, 54].

- agecat2 separates age into the following four categories: [23, 29], $[30,34],[35,44],[45,54]$.

- texpcat separates teaching experience into the following categories: $[0,4],[5,9],[10,14],[15,19]$.

- nkidscat is equal to the number of children if this is equal 0,1 , or 2 . If the number of children is 3 or above, then nkidscat $=3$. (In the data, there are at most four children per individual).

The sectors for which we have wages in the ELD data are municipal school, private-unsubsidized school, and private-subsidized school. No wages are available for the nonteaching sector. 
We match squared wages because we truncated outliers in the wage distribution. Matching wage variances would be infeasible because it would introduce a dependence across individuals that would make the estimation of the variance/covariance matrix of the moments too costly computationally.

List of moments:

(i) wage and wage squared by sector, agecat1, gender

(ii) wage and wage squared by sector, texpcat and gender

(iii) wage and wage squared by sector, nkidscat and gender

(iv) fractions in sectors $\mathrm{M}, \mathrm{V}, \mathrm{U}$ by texpcat and gender ${ }^{55}$

(v) fractions in sectors $\mathrm{M}, \mathrm{V}, \mathrm{U}$ by nkidscat and gender

(vi) fractions in sectors $\mathrm{M}, \mathrm{V}, \mathrm{U}$ by agecat2 and gender

(vii) fraction of individuals working in a teaching occupation who are laid off by texpcat

(viii) fraction of females who have a child by agecat1, nkidscat, whether they had a child in the previous period (up to age 44)

(ix) fraction of males who have a child by agecat1males, nkidscat, whether they had a child in the previous period (up to age 49)

(x) transition probabilities from sectors M V U to sectors M V U by gender (we do not match transitions from and to sectors NT and $\mathrm{H}$ because there are too few observations)

\section{Moments Using the EPSnt (EPS-Nonteacher) Data Set}

We match 106 moments to the EPSnt. The following are the EPSnt categories used in constructing the moments:

- agecat 1 separates age into the following three categories: [22, 34], $[35,44],[45,54]$.

- agecat2 separates age into the following four categories: [22, 29], $[30,34],[35,44],[45,54]$.

- ntexpcat separates nonteaching experience into the following categories: $[0,4],[5,9],[10,14],[15,19]$.

- nkidscat is equal to the number of children if this is equal 0,1 , or 2 . If the number of children is three or above, then nkidscat $=3$. (In the data, there are at most five children per individual).

Wages are available only for the nonteaching occupation, as the individuals in EPSnt are not certified to teach. The following is a list of EPSnt moments used in estimation:

${ }^{55}$ We do not match fractions in NT and H because there are too few observations. 
(i) wage and wage squared by agecat 1 and gender

(ii) wage and wage squared by ntexpcat and gender

(iii) wage and wage squared by nkidscat and gender

(iv) fraction in sector NT by ntexpcat and gender

(v) fraction in sector NT by nkidscat and gender

(vi) fraction in sector NT by agecat 2 and gender

(vii) fraction of individuals working in a nonteaching occupation laid off by ntexpcat

(viii) fraction of individuals who have a child by gender, agecat2, nkidscat and whether they had a child the previous period (up to age 44 for female and 49 for males)

(ix) persistence in sectors NT and $\mathrm{H}$ by gender ${ }^{56}$

\section{Moments Using Data from $a_{\mathrm{G}}$}

In the first period of the model, at the age of graduation/certification $\left(a_{\mathrm{G}}\right)$, individuals choose between a teaching certification and getting a nonteaching college degree. We match two moments:

(x) the fraction of males who get certified

(xi) the fraction of females who get certified

using the EPS data. ${ }^{57}$

\section{B2. Structure of the Variance Covariance Matrix of the Moment Conditions}

The variance covariance matrix $V$, used in the computation of the parameter standard errors, is a square symmetric matrix with a number of rows equal to the total number of moments matched, 337. Because the individuals in ELD and EPS are different, there is no covariance between the moments pertaining to individuals from different data sets. Hence $V$ is a block diagonal matrix with two block matrices on the diagonal: one corresponding to the EPS moments ( $\left.V_{\mathrm{EPS}}\right)$ and one corresponding to the ELD moments $\left(V_{\mathrm{ELD}}\right)$.

The matrix $V_{\text {EPS }}$, occupying rows and columns 1-108 of $V$, contains the variance of the moments related to the choices of nonteachers (EPSnt) from time period 1 onward, the variance of the moments relative to the choice of certification at time 0 , and their covariances. Rows and columns

\footnotetext{
${ }^{56}$ We match only persistence because transition to the other sector is defined residually.

${ }^{57}$ The fraction getting certified is not observed in the ELD data set, which only contains information on teachers.
} 
109-337 contain $V_{\mathrm{ELD}}$, the matrix of the moments relative to the choices of teachers (ELD) from time period 1 onward.

\section{References}

Auguste, Sebastian, and Juan Pablo Valenzuela. 2003. Do students benefit from school competition? Evidence from Chile. Unpublished manuscript, University of Michigan.

Bacolod, Marigee. 2007. Who teaches and where they choose to teach: College graduates of the 1990s. Educational Evaluation and Policy Analysis 29, no. 3:155-68.

Ballou, Dale, and Michael Podgursky. 1995. Recruiting smarter teachers. Lournal of Human Resources 30, no. 2:326-38.

. 1997. Teacher pay and teacher quality. Kalamazoo, MI: WE Upjohn Institute.

Ben-Porath, Yoram. 1967. The production of human capital and the life cycle of earnings. Lournal of Political Economy 75, no. 4:352-65.

Bohlmark, Anders, and Mikael Lindahl. 2008. Does school privatization improve educational achievement? Evidence from Sweden's voucher reform. IZA Working Paper 3691, Institute for the Study of Labor, Bonn.

Bravo, David, Dante Contreras, and Claudia Sanhueza. 1999. Rendimiento escolar, desigualdad, y brecha de desempeño privado/público: Chile, 1982-1997 (School performance inequality and the gap in private/ public performance: Chile, 1982-1997). Working paper no. 163, Department of Economics, University of Chile.

Bravo, David, Bárbara Flores, and Patricia Medrano. Se premia la habilidad en el mercado laboral docente? Cuánto impacta en el desempeño de los estudiantes? (Rewarding ability in the teacher labor market: What are the impacts on student performance?) Working paper, Department of Economics, University of Chile.

Brewer, Dominic J. 1996. Career paths and quit decisions: Evidence from teaching. Lournal of Labor Economics 14, no. 2:313-39.

Carnoy, Martin. 1997. Is privatization through education vouchers really the answer? A comment on West. World Bank Research Observer 12, no. 1:105-16.

Card, David, Martin Dooley, and Abigail Payne. 2008. School competition and efficiency with publicly funded Catholic schools. NBER Working Paper no. 14176, National Bureau of Economic Research, Cambridge, MA.

Chan, Ping Ching Winnie. 2009. School choice, competition, and public school performance. PhD diss., University of Toronto.

Chen, Dandan. 2009. The economics of teacher supply in Indonesia. World Bank Policy Research Working Paper Series no. 4975, World Bank, Washington, DC. 
Clotfelter, Charles, Elizabeth Glennie, Helen Ladd, and Jacob Vigdor. 2008. Would higher salaries keep teachers in high-poverty schools? Evidence from a policy intervention in North Carolina. Iournal of Public Economics 92, nos. 5-6:1352-70.

Contreras, Dante. 2002. Vouchers, school choice, and access to higher education. Economic Growth Center Discussion Paper no. 845, Yale University.

Corcoran, Sean P., William N. Evans, and Robert S. Schwab. 2004. Changing labor market opportunities for women and the quality of teachers, 1957-1992. American Economic Review: Papers and Proceedings 94, no. 2:230-35.

Correa, Juan A., Francisco Parro, and Loreto Reyes. 2015. Self-selection in the market of teachers. Applied Economics 47, no. 13:1331-49.

Dolton, Peter J. 1990. The economics of UK teacher supply: The graduate's decision. Economic Iournal 100, no. 400:91-104.

Dolton, Peter J., and Kostas G. Mavromaras. 1994. Intergenerational occupational choice comparisons: The case of teachers in the UK. Economic Journal 104, no. 425:841-63.

Dolton, Peter J., and Wilbert van der Klaauw. 1995. Leaving teaching in the UK: A duration analysis. Economic Journal 105, no. 429:431-44. . 1999. The turnover of teachers: A competing risks explanation. Review of Economics and Statistics 81, no. 3:543-52.

Elacqua, Gregory. 2006. Public, Catholic, and for-profit school enrollment practices in response to vouchers: Evidence from Chile. Paper 124, National Center for the Study of Privatization in Education, Teachers College, Columbia University.

Falch, Torberg. 2010. The elasticity of labor supply at the establishment level. Lournal of Labor Economics 28, no. 2:237-66.

2011. Teacher mobility responses to wage changes: Evidence from a quasi-natural experiment. American Economic Review 101, no. 3:46065.

Ferreyra, Maria. 2007. Estimating the effects of private school vouchers in multi-district economies. American Economic Review 97, no. 3:787-817.

Figlio, David N. 2002. Can public schools buy better-qualified teachers? Industrial and Labor Relations Review 55, no. 4:686-99.

Figlio, David, and Cassandra M. D. Hart. 2014. Competitive effects of means-tested school vouchers. American Economic Iournal: Applied Economics 6, no. 1:133-56.

Gallego, Francisco A. 2002. Competencia y resultados educativos: Teoria y evidencia para Chile (Competition and educational results: Theory and evidence for Chile). Cuardenos de economía 39, no. 118:309-52.

Gibbons, Stephen, Olmo Silva, and Stephen Machin. 2008. Choice, competition, and pupil achievement. Iournal of the European Economic Association 6, no. 4:912-47. 
Gourierioux, Christian, and Alain Monfort. 2002. Simulation-based econometric methods. Oxford: Oxford University Press.

Greenbaum, Robert T. 2002. A spatial study of teachers' salaries in Pennsylvania school districts. Lournal of Labor Research 23, no. 1:69-86.

Guarino, Cassandra M., Abigail B. Brown, and Adam E. Wyse. 2011. Can districts keep good teachers in the schools that need them most? Economics of Education Review 30, no. 5:962-79.

Hanushek, Eric A., John F. Kain, and Steven G. Rivkin. 1999. Do higher salaries buy better teachers? NBER Working Paper no. 7082, National Bureau of Economic Research, Cambridge, MA. http://www.nber.org /papers/w7082.

Hanushek, Eric A., and Steven G. Rivkin. 2006. Teacher quality. In Handbook of the economics of education, ed. Eric Hanushek and Finnis Welch, 1051-78. Amsterdam: Elsevier.

Heckman, James J., and Guilherme Sedlacek. 1985. Heterogeneity, aggregation, and market wage functions: An empirical model of self-selection in the labor market. Iournal of Political Economy 93, no. 6:1077-1125.

Heckman, James, and Burton Singer. 1984. A method for minimizing the impact of distributional assumptions in econometric models for duration data. Econometrica 52, no. 2:271-320.

Hernani-Limarino, Werner. 2005. Are teachers well paid in Latin America and the Caribbean? Relative wage and structure of returns of teachers. In Incentives to improve teaching: Lessons from Latin America, ed. Emiliana Vegas, 63-102. Washington, DC: World Bank.

Hoxby, Caroline. 2002. Would school choice change the teaching profession? Lournal of Human Resources 37, no. 4:846-91.

2003a. Could school choice be a tide that lifts all boats? In The economics of school choice, edited by Caroline M. Hoxby, 287-342. Chicago: University of Chicago Press.

- 2003b. Introduction. In The economics of school choice, ed. Caroline M. Hoxby, 1-22. Chicago: University of Chicago Press.

Hsieh, Chang-Tai, and Miguel Urquiola. 2003. When schools compete, how do they compete? An assessment of Chile's nationwide school voucher program. NBER Working Paper no. 10008, National Bureau of Economic Research, Cambridge, MA.

2006. The effects of generalized school choice on achievement and stratification: Evidence from Chile's voucher program. Lournal of Public Economics 90, nos. 8-9:1477-1503.

Imazeki, Jennifer. 2005. Teacher salaries and teacher attrition. Economics of Education Review 24, no. 4:431-49.

Ingersoll, Richard M. 2003. The teacher shortage: Myth or reality? Educational Horizons 81, no. 3:146-52.

Keane, Michael P., and Kenneth I. Wolpin. 1997. The career decisions of young men. Lournal of Political Economy 105, no. 3:473-522. 
Keane, Michael P., Petra E. Todd, and Kenneth I. Wolpin. 2010. The structural estimation of behavioral models: Discrete choice dynamic programming methods and applications. In Handbook of labor economics, vol. 2, ed. David Card and Orley Ashenfelter, 332-461. Amsterdam: Elsevier.

Krueger, Alan, and Pei Zhu. 2004. Another look at the New York City school voucher experiment. American Bebavioral Scientist 47, no. 5:65898.

Ladd, Helen. 2002. School vouchers: A critical view. Iournal of Economic Perspectives 16, no. 4:3-24.

Manski, Charles F. 1987. Academic ability, earnings, and decision to become a teacher: Evidence from the National Longitudinal Study of the High School Class of 1972. In Public sector payrolls, ed. David A. Wise, 291-316. Chicago: University of Chicago.

McEwan, Patrick J. 2001. The effectiveness of public, Catholic, and nonreligious private schools in Chile's voucher system. Education Economics 9, no. 2:103-28.

McEwan, Patrick J., and Martin Carnoy. 2001. The effectiveness and efficacy of private schools in Chile's voucher system. Educational Evaluation and Policy Analvsis 22, no. 3:213-39.

Mizala, Alejandra, and Pilar Romaguera. 2005. Teachers' salary structure and incentives in Chile. In Incentives to improve teaching: Lessons from Latin America, ed. Emiliana Vegas, 103-50. Washington, DC: World Bank.

Mont, Daniel, and Daniel I. Rees. 1996. The influence of classroom characteristics on high school teacher turnover. Economic Inauiry 34, no. 1: 152-67.

Murnane, Richard J., and Randall J. Olsen. 1989. The effects of salaries and opportunity costs on duration in teaching: Evidence from Michigan. Review of Economics and Statistics 71, no. 2:347-52.

. 1990. The effects of salaries and opportunity costs on length of stay in teaching: Evidence from North Carolina. Iournal of Human Resources 25 , no. 1:106-24.

Neal, Derek. 2002. How vouchers would change the market for education. Iournal of Economic Perspectives 16, no. 4:25-44.

Newey, Whitney, and Daniel McFadden. 1994. Large sample estimation and hypothesis testing. In Handbook of econometrics, vol. 4, ed. Robert F. Engle and Daniel L. McFadden, 2111-2245. Amstersdam: Elsevier.

Ondrich, Jan, Emily Pas, and John Yinger. 2008. The determinants of teacher attrition in upstate New York. Public Finance Review 36, no. 1: 112-44.

Podgursky, Michael, Ryan Monroe, and Donald Watson. 2004. The academic quality of public school teachers: An analysis of entry and exit behavior. Economics of Education Review 23, no. 5:507-18.

Rees, Daniel I. 1991. Grievance procedure strength and teacher quits. Industrial and Labor Relations Review 45, no. 1:31-43. 
Richards, Craig E., and Tian Ming Sheu. 1992. The South Carolina School Incentive Reward Program: A policy analysis. Economics of Education Review 11, no. 1:71-86.

Rivkin, Steven G., Eric A. Hanushek, and John F. Kain. 2005. Teachers, schools, and academic achievement. Econometrica 73, no. 2:417-58.

Rouse, Cecilia. 1998. Private school vouchers and student achievement: The effect of the Milwaukee parental choice program. Ouarterly Journal of Economics 113, no. 2:553-602.

Roy, Andrew D. 1951. Some thoughts on the distribution of earnings. Oxford Economic Papers 3, no. 2:135-46.

Sandstrom, F. Mikael, and Fredrik Bergström. 2005. School vouchers in practice: Competition will not hurt you. Iournal of Public Economics 89, nos. 2-3:351-80.

Sapelli, Claudio, and Bernardita Vial. 2002. The performance of private and public schools in the Chilean voucher system. Cuaderos de economia 39, no. 118:423-54.

Scafidi, Benjamin, David L. Sjoquist, and Todd R. Stinebrickner. 2006. Do teachers really leave for higher paying jobs in alternative occupations? B. E. Journal of Economic Analysis and Policy: Advances in Economic Analysis and Policy 6, no. 1:1-42.

Shin, Jaeun, and Sangho Moon. 2006. Fertility, relative wages, and labor market decisions: A case of female teachers. Economics of Education Review 25, no. 6:591-604.

Stinebrickner, Todd R. 1998. An empirical investigation of teacher attrition. Economics of Education Review 17, no. 2:127-36.

2001a. Compensation policies and teacher decisions. International Economic Review, 42, no. 3:751-80.

- 2001b. A dynamic model of teacher labor supply. Iournal of Labor Economics 19, no. 1:196-230.

Theobald, Neil D. 1990. An examination of the influence of personal, professional, and school district characteristics on public school teacher retention. Economics of Education Review 9, no. 3:241-50.

Theobald, Neil D., and R. Mark Gritz. 1996. The effects of school district spending priorities on the exit paths of beginning teachers leaving the district. Economics of Education Review 15, no. 1:11-22.

Tincani, Michela Maria. 2014. School vouchers and the joint sorting of students and teachers. Human Capital and Economic Opportunity Global Working Group, Working Paper no. 2014-012, Economics Research Center, University of Chicago.

Tokman, Andrea Ramos. 2002. Is private education better? Evidence from Chile. Working Paper of Central Bank of Chile 147. Central Bank of Chile.

Vegas, Emiliana. 2002. School choice, student performance, and teacher and school characteristics: The Chilean case. World Bank Report, World Bank, Washington, DC. 
Verhoogen, Eric, and Miguel Urquiola 2009. Class-size caps, sorting, and the regression-discontinuity design. American Economic Review 99, no. 1:179-215.

West, Martin, and Ludger Woessman. 2010. Every Catholic child in a Catholic school? Historical resistance to state schooling, contemporary private competition and student achievement across countries. Economic Lournal 12, no. 546:229-55.

Wiswall, Matthew. 2007. Licensing and occupational sorting in the market for teachers. Unpublished manuscript, Department of Economics, New York University.

Wolter, Stefan C., and Stefan Denzler. 2004. Wage elasticity of the teacher supply in Switzerland. Brussels Economic Revierw 47, nos. 3-4:387-407.

Yau, Jeffrey. 2004. Estimating the impact of vouchers when the impact depends on the duration of program participation. PhD diss., University of Pennsylvania. 